\title{
Corporate Governance and Commercial Banking: A Comparative Examination of Germany, Japan, and the United States
}

\author{
Jonathan R. Macey* \& Geoffrey P. Miller**
}

The current paradigm of corporate governance theory suggests that the Japanese main bank system and the German universal bank system encourage socially optimal corporate decisionmaking. Unlike their Japanese and German counterparts, American banks are barred from taking an active role in corporate governance, both by laws restricting share ownership, and by legal rules which hold banks liable for exerting managerial control over borrowers. The debate among commentators has focused on whether the German and Japanese systems should be viewed as alternatives to the American model. In this article, Professors Macey and Miller challenge the current paradigm by demonstrating that powerful banks may prevent equity claimants from undertaking socially optimal risks, thereby hindering the development of robust capital markets. They conclude that the most effective model is one which large-block shareholders pose a credible threat to incumbent management and banks maximize their comparative advantage in controlling moral hazard.

\section{INTRODUCTION}

In recent years, legal scholars have frequently criticized America's traditional system of corporate governance, routinely depicting it as having "sharply constrained the development of multidimensional governance relationships."1

* J. DuPratt White Professor of Law and Director, John M. Olin Program in Law and Economics at Comell Law School.

** Kirkland \& Eliis Professor and Director, Program in Law and Economics at the University of Chicago Law School.

This paper benefitted from comments and suggestions from Franklin Allen, Clas Bergstrom, Enrico Colombatto, Frank Easterbrook, Steven Kaplan, Lynn LoPocki, Russell Osgood, Jeff Rachlinsky, Roberta Romano, Stewart Schwab, and Alan Schwartz. Macey is grateful for discussions with Stewart Schwab clarifying Japanese and German banks' bargaining behavior, and gratefully acknowledges research support from the John M. Olin Foundation, the International Centre for Economic Research in Turin, Italy, and Cornell Law School. Useful comments on this paper also were received at faculty workshops at Cornell Law School and the University of Michigan Law School as well as at the Structure of Corporate Governance Conference of the Financial Markets Group of the London School of Economics, and particularly, at the Nobel Foundation Symposium "Law and Finance: Corporate Governance and Financial Contracting," in Stockholm. The authors are grateful for the research assistance provided by Kevin D. Hartzell, Comell Law School, 1996.

1. Ronald T. Gilson \& Reinier Kraakman, Investment Companies as Guardian Shareholders: The Place of the MSIC in the Corporate Governance Debate, 45 STAN. L. REv. 985, 989 (1993); see also 
In particular, scholars have argued that American mechanisms for monitoring and controlling corporate managers are grossly inferior to those of Japan and Germany. They describe American firms disparagingly as "Berle-Means" corporations, ${ }^{2}$ with widespread share-ownership, separation of management and risk-bearing, and significant agency conflicts between managers and shareholders. ${ }^{3}$ Despite some protestations of agnosticism, ${ }^{4}$ the critics' tone makes it clear that they regard the American system of corporate governance as inferior because it fails to foster the sort of "relational investing" that leads to effective monitoring by sophisticated intermediaries. ${ }^{5}$

At its core, the modern romanticism surrounding German and Japanese corporate governance turns on the role played by commercial banks. The dominant idea is that commercial banks, if allowed to function free of regulation, are able to monitor and influence the business affairs of borrowing corporations. United States law, however, limits banks' influence to a suboptimal level '[b]y restricting the size of banks and the scope and geographical range of their activities." Because American banks lack both the power and incentive to monitor their borrowers,

the monitoring role in the American corporate governance system is relegated to those who provide only equity capital to the corporation - the shareholders. This characteristic has forced American governance institutions to follow a unique Berle-Means pattern of successive efforts, ranging from independent directors to hostile takeovers, to bridge the separation of ownership and management in the face of dispersed shareholdings. ${ }^{7}$

Mark J. Roe, A Political Theory of American Corporate Finance, 91 ColuM. L. REv. 10, 13-16 (199I) (discussing recent criticisms of the U.S. corporate governance system).

2. The term "Berle-Means" corporation is derived from the classic text describing the separation of ownership and control in the large public corporation, AdOLPH A. BERLE, JR. \& GARDINER C. MEANS, The Modern Corporation and Private Property (1932).

3. Indeed, some commentators have concluded that shareholder passivity, combined with disaggregated share ownership, allows management to dominate corporate governance at almost every tum. See, e.g., Carol Goforth, Proxy Reform as a Means of Increasing Shareholder Participation in Corporate Governance: Too Little, but Not Too Late, 43 AM. U. L. REv. 379, 413-14 (1994) (stating that the American corporate governance system, with its structural emphasis on dominant management and widespread shareownership, has led to self-interested and inefficient decisionmaking by management).

4. Mark Roe, one of the most important authors in this movement, claims to examine Germany and Japan "not to argue that their corporate structures are better and should be mimicked, but to show that different structures are possible." Mark J. Roe, Some Differences in Corporate Structure in Germany, Japan, and the United States, 102 Y ALE L.J. 1927, 1997 (1993).

5. Roe, for example, writes that "the American pattern of fragmented shareholders with little power is not inevitable" and that corporate "managers can share power with intermediaries without making the corporate world fall apart." Id.; see also Bernard S. Black, Agents Watching Agents: The Promise of Institutional Investor Voice, 39 U.C.L.A. L. REv. 811, 813-14 (1992) (noting that, absent America's legal restrictions, institutional investors can and do effectively monitor corporations); Jeffrey $\mathrm{N}$. Gordon, Institutions as Relational Investors: A New Look at Cumulative Voting, 94 CoLUm. L. Rev. 124,127 (1994) (arguing that appropriate changes in legal rules will allow institutional investors to promote the quality, independence, and accountability of the board); Michael E. Porter, Capital Disadvantage: America's Failing Capital Investment System, HARv. Bus. Rev., Sept.-Oct. 1992, at 65, 76-77 ("The interests of capital providers must be aligned with those of the corporation so that investors seek out high-quality information that fosters more appropriate investment choices.").

6. Gilson \& Kraakman, supra note 1 , at 989.

7. Id. at 990 . 
In short, critics suggest that American banks should play a role similar to that of German universal banks and of Japanese main banks, monitoring and shaping the management of corporate borrowers. ${ }^{8}$ Commentators have explicitly argued that without major changes in American banking law and practice "the United States is likely ... to lag behind its European and Japanese competitors."

In this article, we cast doubt on the desirability of commercial bank involvement in corporate governance. We argue that proponents of bank involvement not only fail to address the significant costs of the Japanese and German systems of bank-dominated corporate governance, but ignore important benefits of the American system of equity-dominated corporate governance as well. Advocates of bank influence also ignore critical differences between the monitoring incentives of equity holders and the monitoring incentives of debt holders. Much of the confusion in the current debate stems from a failure to appreciate the economics of commercial banking in general and of commercial bank lending in particular. Once the economics and incentives of commercial banking are understood, it becomes clear that greater bank involvement in the governance of American corporations will not cure the problems created by the separation of ownership and control. Rather, bank involvement carries with it an entirely new set of conflicts between the risk-averse claimants who make loans and the residual claimants who invest risk capital. For this reason, America is better off trying to repair its own corporate governance system than it would be adopting an entirely new system, with all its attendant problems.

Part I describes the conflict of interest between a firm's fixed claimants including banks on the one hand, and a firm's equity claimants on the other. Understanding this conflict is critical to an analysis of the supposed advantages that the German and Japanese systems have over the American system. We show that the current paradigm's core assumption about the role of banks in corporate governance-namely, that what is good for a nation's banks is also good for the nation's borrowers-is flawed. Utilizing basic principles of corporate finance, we show that, to the extent that banks control corporate borrowers, they are likely to reduce corporate risktaking below the socially optimal level.

Part II discusses the German and Japanese corporate governance systems against the background of the conflict described in Part I. In both systems, banks exert more influence in corporate decisionmaking than in the United States. And in both of these systems the banks have used this influence to reduce risktaking among borrowers and to retard the market for corporate control. Current wisdom holds that the German and Japanese banking systems substitute for robust markets for corporate control because such systems reduce agency costs and improve managerial performance. ${ }^{10}$ We argue that the Japanese and German bank-dominated systems of corporate governance actually

8. See, e.g., Roe, supra note 4 , at 1928-29.

9. ANthony Saunders \& Ingo Walter, Universal Banktng in the United States: What Courd We Gan? What COUtD We Lose? 236 (1994).

10. See notes $32 \& 67$ infra and accompanying texts. 
prevent the development of robust markets for corporate control in those countries.

Part III develops a theory of banks' role in the economy in order to analyze the role of banks in corporate governance. Like all fixed claimants, banks attempt to control moral hazard ${ }^{11}$ and adverse selection ${ }^{12}$ by borrowers. Unlike other financial intermediaries, however, which tend to specialize in solving adverse selection problems, banks specialize in controlling moral hazard problems.

Controlling moral hazard is more critical for banks than for other types of firms for three reasons. First, borrowers with the most severe moral hazard problems gravitate disproportionately to banks. Second, banks, unlike other firms, fund their loan portfolios primarily with checking accounts available to depositors on demand. The resulting mismatch in the term structure between assets and liabilities makes them more susceptible to short-term fluctuations in cash flows. Finally, banks are among the most highly leveraged firms in the economy, again ensuring their vulnerability to even minor fluctuations in borrowers' cash flows. Therefore, the nature of banks' balance sheets, which are typically characterized by both high leverage and a mismatch in the term structure of assets and liabilities, causes banks - even German universal banks that hold both debt and equity - to be more concerned with risk reduction than with risktaking in the firms in which they have made investments. In other words, banks have stronger incentives than other fixed claimants to control the activities of their borrowers in general and to control moral hazard in particular.

Part IV discusses the efficiency implications of our theory, and the implications for international comparisons of bank size and profitability. We hypothesize that German and Japanese banks will be more profitable than American banks because they are better able to monitor and control borrowers' moral hazard. We emphasize, however, that the profitability of these banks not only prevents firms from undertaking profitable investment opportunities, but also prevents the future development of robust primary and secondary capital markets.

Part V explores the implications of our observations for the ongoing debate about American corporate governance. We argue that simply giving fixed claimants more power over borrowers will not solve the perceived problems in American corporate governance. Rather, firm performance can be more effectively enhanced by eliminating restrictions on the market for corporate control, thereby improving the voice of American equity holders. Moreover, we argue that critical features of American law-including environmental law, partnership law, and lender liability rules-limit the ability of banks to monitor and control the moral hazard of borrowing firms to the same extent as European rules allow. For these reasons, universal banking offers fewer benefits than is

11. The term "moral hazard" describes the risk lenders face because borrowers have incentives to increase the riskiness of their projects after obtaining loans. See note 93 infra and accompanying text.

12. The term "adverse selection" describes the risk lenders face because high-risk borrowers, who apply for loans in disproportionate numbers, are difficult to distinguish from low-risk borrowers. See note 92 infra and accompanying text. 
commonly perceived, and other, more incremental changes in legal rules offer greater potential rewards.

Finally, Part VI discusses preconditions for convergence among the corporate governance systems of the United States, Germany, and Japan. We argue that convergence is unlikely for several reasons, including resistance by German and Japanese banks, the presence of strong institutional investors in the United States, and path dependence. Because American banks are unlikely to achieve the same dominance over American firms as German and Japanese banks have over firms in their own countries, we support proposals to liberalize the Glass-Steagall Act and the Bank Holding Company Act. We conclude that liberalization of the banking rules will strengthen the American banking industry without enabling banks to transfer wealth to themselves at the expense of other shareholders.

\section{The Conflict of Interest Between "Pure" Equity Claimants AND BANKS}

Modern corporate finance scholars have formalized the conflict of interest that exists within the publicly held corporation between the interests of fixed claimants (such as banks) and the interests of shareholders who hold residual claims to the firm's earnings. ${ }^{13}$ When choosing how to allocate assets, firms that increase risk will transfer wealth from the fixed claimants to the residual claimants. ${ }^{14}$ Thus, to the extent that shareholders can influence corporate decisions through their voting power, they can enrich themselves at the expense of fixed claimants by shifting assets to risky investments. Similarly, to the extent that banks and other fixed claimants can influence corporate decisions through corporate governance structures (or, as in Germany, through their ability to vote shares owned by others), they can enrich themselves at the expense of shareholders. The following example illustrates this point.

Suppose that a borrower has assets of $\$ 1000$ and liabilities of $\$ 500$. Assume the $\$ 500$ represents the principal and interest due on money borrowed from banks. This leaves the firm with $\$ 500$ in shareholders' equity. The firm must choose between investment strategy $A$, which has an expected payoff of $\$ 2020$ and investment strategy $B$, which has an expected payoff of $\$ 1875.15$

13. See, e.g., William A. Kiein \& John C. Coffee, JR., Business Organization and Finance: Legal and Economic Principles 225-26 (5th ed. 1993); Barry E. Adler, Finance's Theoretical Divide and the Proper Role of Insolvency Rules, 67 S. CAL. L. REv. 1107 (1994); Frank H. Easterbrook \& Daniel R. Fischel, The Corporate Contract, 89 Conum. L. Rev. 1416 (1989); David Millon, Theories of the Corporation, 1990 DUKE L.J. 201. This discussion and the example that follows have been adapted from our previous article, Jonathan R. Macey \& Geoffrey P. Miller, Bank Failures, Risk Monitoring, and the Market for Bank Control, 88 CoLum. L. REv. 1153 (1988).

14. KLEN \& COFFEE, supra note 13, at 257 ("From any starting point, holding the total market value of the firm and of all securities constant, a decision that shifts investments in such a way as to increase such risk will result in an increase in the value of the common and a decrease in the value of the bonds."); Roberta Romano, Financing the Corporation, in Foundations of CORPORATE LAW 123 (Roberta Romano ed., 1993).

15. For investment strategy $A$, assume that there are five possible outcomes, represented by the firm's monetary returns in the second column of the table for Strategy A. The probability of each of these outcomes occurring is shown in the first column. Regardless of the outcome, the firm pays the 
Strategy A:

MONETARY RETURN

EXPECTED VALUE

\begin{tabular}{|c|c|c|c|c|c|c|}
\hline PROBABILITY & FIRM & BANK & COMMON & FIRM & BANK & COMMON \\
\hline .05 & $\$ 400$ & $\$ 400$ & $\$ 0$ & $\$ 20$ & $\$ 20$ & $\$ 0$ \\
\hline .20 & $\$ 1000$ & $\$ 500$ & $\$ 500$ & $\$ 200$ & $\$ 100$ & $\$ 100$ \\
\hline .50 & $\$ 2000$ & $\$ 500$ & $\$ 1500$ & $\$ 1000$ & $\$ 250$ & $\$ 750$ \\
\hline .20 & $\$ 3000$ & $\$ 500$ & $\$ 2500$ & $\$ 600$ & $\$ 100$ & $\$ 500$ \\
\hline .05 & $\$ 4000$ & $\$ 500$ & $\$ 3500$ & $\$ 200$ & $\$ 25$ & $\$ 175$ \\
\hline 1.00 & & & & $\$ 2020$ & $\$ 495$ & $\$ 1525$ \\
\hline
\end{tabular}

STRATEgy B:

MONETARY RETURN

EXPECTED VALUE

\begin{tabular}{|c|c|c|c|c|c|c|}
\hline PROBABILITY & FIRM & BANK & COMMON & FIRM & BANK & COMMON \\
\hline .25 & $\$ 1000$ & $\$ 500$ & $\$ 500$ & $\$ 250$ & $\$ 125$ & $\$ 125$ \\
\hline .50 & $\$ 2000$ & $\$ 500$ & $\$ 1500$ & $\$ 1000$ & $\$ 250$ & $\$ 750$ \\
\hline .25 & $\$ 2500$ & $\$ 500$ & $\$ 2000$ & $\$ 625$ & $\$ 125$ & $\$ 500$ \\
\hline 1.00 & & & & $\$ 1875$ & $\$ 500$ & $\$ 1375$ \\
\hline
\end{tabular}

As the table for strategy $A$ indicates, there is a 5 percent chance that the bank will suffer a small loss because, if the investment returns only $\$ 400$, the firm will be unable to repay the full $\$ 500$ loan. In contrast, strategy B poses absolutely no risk of loss to the bank because, even under the worst possible scenario, strategy B returns enough to repay in full the principal and interest on the firm's bank debt.

There are, however, two other important differences between strategies $\mathrm{A}$ and B. First, strategy B is significantly inferior to strategy A from the shareholders' perspective. Strategy B has an expected return for shareholders of only $\$ 1375$, compared with an expected shareholder return of $\$ 1525$ for strategy A. The demonstrated disparity in expected returns may be explained by the simple fact that strategy $A$ has both a greater potential upside and a greater potential downside than strategy B. Because the equity claimants capture all of the gains on the upside after the bank has been repaid, but share the losses on the downside with the bank, they obviously prefer the riskier investment.

Strategy B also is inferior from the perspective of society as a whole, since the expected value of strategy $A$ is $\$ 2020$, compared with only $\$ 1875$ for strategy B. Thus, if an economy were to allocate plenary authority over investment decisions to fixed claimants such as banks, productivity and gross domestic product would decline to suboptimal levels as the banks steered investments away from the highest-valued projects and toward lower-valued projects. Thus,

bank first and any residual accrues to the common shareholders. The expected value of each outcome to the firm, the bank, and the common shareholders is simply the monetary retum multiplied by the probability that it will occur. The sums of the expected values represent the overall expected values of investment strategy $A$ to the firm, the bank, and the equity holders. All of the investment strategies discussed in this example follow the same basic outline. 
as Frank Easterbrook and Daniel Fischel have observed, as residual claimants under American corporate governance structures, shareholders retain plenary authority to guide investment decisions because, over a wide range of issues, it is the shareholders who have the greatest incentive to maximize the value of the firm. ${ }^{16}$

Of course, just as it would be sub-optimal to give plenary authority to the firm's fixed claimants, so also would it be sub-optimal to give plenary authority over all investment decisions to the equity claimants: Equity claimants have an incentive to transfer wealth to themselves by increasing the riskiness of the firm in which they have invested. Left to their own devices, the shareholders might select strategy $\mathrm{C}$, which has the following payoff structure:

\section{STRATEgy C:}

MONeTARY RetUrN

EXPECTED VALUE

\begin{tabular}{|c|c|c|c|c|c|c|}
\hline PROBABILITY & $\underline{\text { FIRM }}$ & BANK & COMMON & FiRM & BANK & COMMON \\
\hline .30 & & 0 & & $\$$ & & \\
\hline .50 & $\$ 1000$ & $\$ 500$ & $\$ 500$ & $\$ 500$ & $\$ 250$ & $\$ 250$ \\
\hline .20 & $\$ 7500$ & $\$ 500$ & $\$ 7000$ & $\$ 1500$ & $\$ 100$ & $\$ 1400$ \\
\hline 1.00 & & & & $\$ 2000$ & $\$ 350$ & $\$ 1650$ \\
\hline
\end{tabular}

Shifting to strategy $\mathrm{C}$ would increase the expected value of the shareholder's stake from $\$ 1525$ under strategy A to $\$ 1650$, but would reduce the expected value of the bank's investment from $\$ 495$ to $\$ 350$, and the total value of the firm from $\$ 2020$ to $\$ 2000$. As before, the risk of each strategy, as represented by the probability of particular outcomes, determines the expected value of each project. For strategy $A$, the standard deviation from its expected value, $\$ 2020$, is relatively small, just $\$ 853 .{ }^{17}$ For strategy $B$, which from the bank's perspective is the best investment among the three, the standard deviation from its expected value of $\$ 1875$ is even less, just $\$ 545.1^{18}$ For strategy $C$, however, the standard deviation from the expected value of $\$ 2000$ is quite large, $\$ 2784 .{ }^{19}$ For this reason, strategy $\mathrm{C}$ is the worst investment among the three from the

16. Frank H. Easterbrook \& Daniel R. Fischel, Voting in Corporate Law, 26 J.L. \& EcoN. 395, 403-06 (1983). But see Eugene F. Fama, Agency Problems and the Theory of the Firm, 88 J. PoL. EcoN. 288, 290-92 (1980) (describing the market for managerial labor as producing the dominant incentive for maximizing the value of the firm).

17. The standard deviation, which provides a convenient index of portfolio risk, summarizes the spread of possible expected outcomes for a portfolio. Richard A. BrEALY \& Stewart C. MYers, PRANCIFles of Corporate FinaNCE 134 (4th ed. 1991). The standard deviation, represented by $\sigma$, is the square root of the variance. The variance is calculated by: $\sigma^{2}=\Sigma(x-\mu)^{2} p(x)$; where $x$ is the dollar outcome, $\mathrm{p}(\mathrm{x})$ is the probability that the outcome will occur, and $\mu$ is the expected value of the investment strategy. Here, $\sigma^{2}=(400-2020)^{2}(.05)+(1000-2020)^{2}(.20)+(2000-2020)^{2}(.50)+(3000-$ $2020)^{2}(.20)+(4000-2020)^{2}(.05)=727,600$. The square root of 727,600 is $\$ 853$, which is the standard deviation of strategy $A$.

18. For strategy $B$, the variance, $\sigma^{2}=(1000-1875)^{2}(.25)+(2000-1875)^{2}(.50)+(2500-1875)^{2}(.25)$ $=296,875$. The standard deviation of strategy $B$ is $\$ 545$.

19. For strategy $\mathrm{C}$, the variance, $\sigma^{2}=(0-2000)^{2}(.30)+(1000-2000)^{2}(.50)+(7500-2000)^{2}(.20)=$ $7,750,000$. The standard deviation of strategy $C$ is $\$ 2784$. 
bank's perspective, but the best from the shareholder's perspective. ${ }^{20}$ The shareholders capture the lion's share of the huge upside potential associated with strategy $\mathrm{C}$, but share the downside loss with the bank.

In a properly functioning capital market, an equilibrium emerges from the disparate interests of fixed claimants, equity claimants, and indeed, all other claimants on the firm's cash flows, such as workers, managers, suppliers, and customers. Rational banks demand compensation in the form of higher interest payments for the danger that they will loan money to firms with investment portfolios resembling B, only to have the firm shift its resources toward A or C. Shareholders, on the other hand, will pay less for stock in firms whose investment patterns resemble strategy $\mathrm{B}$ rather than $\mathrm{A}$ or $\mathrm{C}$.

Through bargaining, the parties can improve on any equilibrium that does not maximize the overall value of the firm. Shareholders, for example, could agree to pay a higher interest rate in exchange for allowing equity claimants to pursue riskier projects. Similarly, bondholders could accept a lower interest rate in exchange for a credible shareholder promise not to shift their investments towards riskier projects after credit has been extended. Thus, the equilibrium that emerges in a properly functioning capital market not only protects both banks and equity holders, but also promotes allocational efficiency (the efficient allocation of resources within society) because it guarantees that investments which maximize the overall value of the firm will be pursued.

Two important insights emerge from the preceding discussion that are relevant to the ongoing debate about alternative corporate governance mechanisms. First, the clear conflict of interest between fixed claimants (including banks) and equity claimants strongly suggests that banks are not ideal institutions to monitor corporate performance on behalf of shareholders. ${ }^{21}$ Second, legal and structural problems within capital markets raise transaction costs, thereby impeding the operation of capital markets and making it more difficult for market participants to resolve the inherent conflicts between fixed and residual claimants-as well as among other participants in the corporate enterprise. Managers, for example, tend to be more risk averse than shareholders because the amount of their compensation is predominantly fixed, aligning their incentives more closely with fixed claimants than with equity claimants. Managers' incentives for risktaking are further reduced because of their investment of nondiversifiable human capital in their jobs. ${ }^{22}$ The value of this human capital would depreciate significantly if their firms were to fail. Transaction costs, particularly the high costs of contracting and the impossibility of predicting the future with certainty, make it is impossible to design executive compensation

20. The degree of outcome variance is not, strictly, the basis for a fixed claimant's aversion to a particular investment scheme. While outcome variance may indicate the likelihood of the borrower's ability to meet fixed claims, it is not necessarily determinative. A fixed claimant is less concerned about upside potential than with downside risk - the probability of an outcome that prevents the borrower from meeting fixed claims. A large outcome variance may result from a substantial disparity between upside and downside potential, or simply from a substantial downside risk.

21. See Easterbrook \& Fischel, supra note 13, at 1444-47 (suggesting that corporate law exists because it minimizes transaction costs to competing interest groups within the corporation).

22. KLEN \& COFFE, supra note 13 , at 266-67. 
contracts that perfectly align the interests of managers with the interests of shareholders. ${ }^{23}$ The deviation of managerial risk preferences from shareholder preferences often results in a suboptimal level of risktaking by firms. ${ }^{24}$

Legal rules and institutions can exacerbate these inefficiencies. Rules that artificially restrict the market for corporate control, or that artificially increase the bargaining power of one group of claimants (e.g., by guaranteeing them places on corporate boards of directors), can prevent investing parties from reaching a wealth maximizing bargaining equilibrium and achieving allocational efficiency.

\section{Romanticizing the Role of German and Japanese Banks}

The critical distinction between the American model and the German and Japanese models of corporate governance is easily summarized. In Germany and Japan, large block shareholders take an active management role to mitigate managerial shirking and misconduct. ${ }^{25}$ By contrast, the American structure of corporate governance largely focuses power in management, particularly in the chief executive officer. ${ }^{26}$ For this reason, American shareholders are relatively powerless to affect management decisions; they are too disaggregated to monitor management's activities, much less to galvanize into effective political coalitions to oppose these activities.

\section{A. The Japanese Main Banking System}

Scholars often romanticize the Japanese main bank system. They argue that Japanese main banks effectively monitor their debtors, helping to prevent business failure and substituting for a robust corporate control market. ${ }^{27}$ The Japanese system of corporate governance is characterized by a complex network of inter-corporate equity holdings, with Japanese banks at the center of the network. ${ }^{28}$ This pattern of cross-holdings makes hostile takeovers virtually unknown in Japan. As a large number of commentators have observed, bank oversight replaces the market for corporate control in Japan. ${ }^{29}$ In the United

23. Id.

24. See Irwin Friend \& Larry H. P. Lang, An Empirical Test of the Impact of Managerial SelfInterest on Corporate Capital Structure, 43 J. FN. 271 (1988). Friend and Lang find that high levels of debt (and hence greater risk) in corporate capital structures correspond to low levels of managerial stock ownership. Id. at 280 . Firms where principal stockholders were not managers tend to assume higher risk levels. Id.

25. See Roe, supra note 4, at 1936-48 (describing the influence of large block shareholders in Japanese and German corporations).

26. Id. at 1928-30. Historically, this concentration of power in American management occurred because the rise of large-scale production capabilities in the late 19th century demanded huge inputs of capital, which could only be supplied by large numbers of disaggregated investors. Id. at 1933.

27. See Ronald J. Gilson \& Mark J. Roe, Understanding the Japanese Keiretsu: Overlaps Between Corporate Governance and Industrial Organization, 102 YALE L.J. 871, 879 (1993) (noting that American commentators were drawn to the Japanese main bank system as a "monitoring paragon").

28. Randall Morck \& Masao Nakamura, Banks and Corporate Control in Japan 4-5 (Institute for Financial Research, Faculty of Business, University of Alberta, Working Paper No. 6-92, rev. July 26,1993 ).

29. See, e.g., Masahiko Aoki, Hugh Patrick \& Paul Sheard, The Japanese Main Bank System: An Introductory Overview, in ThE Japanese MAIN Bank System: Its Relevance for Developing and 
States, the market for corporate control reduces managerial inefficiency and restrains managerial self-interest. A robust corporate control market spurs hostile takeovers; new owners replace inefficient management teams. ${ }^{30}$ Strong evidence indicates that hostile takeovers discipline managers and improve corporate performance. ${ }^{31}$

Recent empirical work shows that the Japanese main bank system serves as a quasi-substitute for the corporate control market. In a study of large Japanese firms in the 1980s, Randall Morck and Masao Nakamura found that:

poor stock market performance in large non-financial firms leads to an increased probability that a bank executive is named to the board of directors the subsequent year. The appointment of a new bank representative to a board is regarded as important by Japanese financial analysts and by the financial press. It is thought to indicate increased bank attention to the company. We also find that liquidity problems are a strong predictor of intervention. Bank intervention is followed by a quick return to industry normal cash flow and liquidity levels. Sales growth and especially employment growth remain low for several years, but eventually recover to industry average levels. This recovery is accompanied by improved stock market performance. Because of the role banks play in the management of troubled firms, we suggest that a hierarchy based on bank oversight to some extent replaces the market for corporate control in Japan. ${ }^{32}$

Three critical features of Japanese corporate governance deserve special emphasis. First, large Japanese firms generally own blocks of shares in other Japanese firms, ${ }^{33}$ which they are unwilling to sell except in unusual circumstances. $^{34}$ Second, Japanese banks, unlike American banks, ${ }^{35}$ can hold and

Transformang Economes 3 (Masahiko Aoki \& Hugh Patrick, eds., 1994) (describing the main bank system as a system of corporate financing and governance in which capital market participants and regulators expect main banks to monitor firms and intervene when things go wrong); Gilson \& Roe, supra note 27, at 879-81; Takeo Hoshi, Anil Kashyap \& David Scharfstein, The Role of Banks in Reducing the Costs of Financial Distress in Japan, 27 J. Fin. ECoN. 67, 70-71 (1990); STEveN N. Kaplan \& Bernadette A. Minton, 'Outside' Intervention in Japanese Companies: Its DetermiNANTS AND ITS IMPLICATIONS FOR MANAGERS 3-4 (National Bureau of Economic Research Working Paper No. 4276, Feb. 1993); Stephen D. Prowse, The Structure of Corporate Ownership in Japan, 47 J. Fin. 1121, 1127 (1992); Paul Sheard, The Main Bank System and Corporate Monitoring and Control in Japan, 11 J. ECON. BEHAV. \& ORG. 399, 407-09 (1989).

30. Henry G. Manne, Mergers and the Market for Corporate Control, 73 J. PoL. Econ. 110, $112-$ 13 (1965) (describing the process of replacing inefficient management).

31. See Michael C. Jensen \& Richard S. Ruback, The Market for Corporate Control: The Scientific Evidence, 11 J. FrN. EcoN. 5, 29-30 (1983) (stating that hostile takeovers limit managerial inefficiency); Randall Morck, Andrei Shleifer \& Robert W. Vishny, Alternative Mechanisms for Corporate Control, 79 AM. ECON. Rev. 842, 851-52 (1989) (studying 454 of the 1980 Fortune 500 firms and finding that hostile takeovers constitute the main force behind the removal of unresponsive firm managers in poorly performing industries).

32. MORCK \& NAKAMURA, supra note 28 , at 3.

33. Gilson \& Roe, supra note 27 , at $882-83$.

34. Morck \& Nakamura, supra note 28, at 4; See also Harald Baum \& Ulrike Schaede, Institutional Investors and Corporate Governance in Japanese Perspective, in INSTITUTIONAL INVESTORS AND Corporate Governance 609, 629-30 (Theodor Baums, Richard M. Buxbaum \& Klaus J. Hopt eds., 1993) (noting that $75 \%$ of Japanese stock is held by "relationship-oriented" investors and that $83.5 \%$ of Nikkei firms believed that $50 \%$ or more of their equity was held by "stable shareholders").

35. Under U.S. law, bank holding companies, but not banks, can own up to $5 \%$ of the stock in a firm that is engaged in activities unrelated to banking, 12 U.S.C. $\S 1843(\mathrm{c})(6)(1994)$, but the investment 
vote substantial (up to 5 percent) blocks of stock in any industrial firm. ${ }^{36} \mathrm{Fi}$ nally, and of utmost importance, the pattern of cross-holdings prevalent in Japan represents a "deliberate response by [Japanese] managers ... to a series of hostile raids in the early post-war years." 37

After World War II, the occupation forces broke up the large corporate groups (zaibatsu) controlled by leading Japanese families and financed by large universal banks. The occupation forces effected the diffusion of ownership by compelling the families to sell their cross-holdings in each other's shares. ${ }^{38}$ By 1950 , cross-holdings of shares was virtually eliminated. ${ }^{39}$ But when the U.S. occupation ended, cross-holdings quickly re-emerged, as managers feared that the depressed prices of their shares would spur hostile takeovers. ${ }^{40}$ In the mid1960s, these new cross-holding networks, called keiretsu, gained in strength as depressed stock prices led to a threat of hostile takeovers, and the large banks (Fuji, Sanwa and Daiichi-Kangyo) "began major efforts to increase cross-holding among firms associated with them, again with the explicit aim of blocking potential hostile takeovers." 41 This pattern repeated itself in the 1970 s. $^{42}$

In keiretsu, member firms own less than 2 percent of the stock in other member firms. Because each member of a keiretsu owns about 2 percent of every other firm in the group, however, between 30 percent and 90 percent of the stock in each firm will be owned by other keiretsu members. ${ }^{43}$ At the center of the keiretsu are the banks, which have seats on corporate boards and can exert pressure on corporate management, particularly when cash flows become unstable. ${ }^{44}$

Management gains from the Japanese pattern of bank domination and crossownership, because the system allows incumbent management to insulate itself from takeovers and thus avoid the strict discipline imposed by the takeover market. As Morck and Nakamura astutely observe, "the pattern of cross holdings among Japanese keiretsu firms is, to a large extent, a deliberate anti-takeover defense system. It serves the same purpose as poison pills, greenmail and shark repellents do in U.S. firms." 45

At first glance, the gains to banks from the keiretsu system appear less evident. But embedded in the cross-holdings is a stable system of equity ownership that eliminates the threat of hostile takeovers which might increase the target firm's leverage and transfer wealth from the fixed claimants (the banks)

must be passive. But see notes 177-185, infra and accompanying text (discussing proposals to reduce the legal barriers facing American banking organizations).

36. MORCK \& NARAMURA, supra note 28 , at 4.

37. Id. at 6 .

38. Id.

39. Id.

40. Id.

41. Id. at 7.

42. Id.

43. Watching the Boss: A Survey of Corporate Governance 8, in Economist, Jan. 29, 1994, at 58 [hereinafter Corporate Governance Survey].

44. Morck \& Naramura, supra note 28 , at 28-29.

45. Id. at 7 . 
to the equity claimants. 46 In addition, banks may use their central roles in Japanese keiretsu to influence the degree of internal risktaking by firms. Consistent with this analysis, Morck and Nakamura find that highly leveraged firms are more likely to have bank representatives appointed to their boards than other firms. ${ }^{47}$ This suggests that banks step in to control risk that might benefit shareholders at the banks' expense.

In sum, over a wide range of corporate governance issues, banks align themselves with the interests of incumbent management and oppose the interests of shareholders. Because both managers and banks have fixed claims on their firms' cash flows, they care far less about maximizing their firms' potential upside performance than about minimizing potential downside performance. Thus, the keiretsu relationship benefits both managers and banks because the relationship reduces the uncertainty associated with the managers' human capital investment and the banks' fixed capital investment. But this implicit contract between banks and the management of publicly held borrowers harms outside shareholders, who would capture all the marginal gains from profitable, but uncertain, investments. For this reason, "[i]t is unclear to what extent public shareholders benefit from bank intervention." 48 In fact, empirical studies find no discernible overall effect on share prices following bank intervention. ${ }^{49}$

When corporations join a keiretsu, they limit their ability to obtain funding from outside banks for two primary reasons. First, outside lenders know that equity cross-holdings will induce keiretsu firms to elect strategies that benefit the keiretsu and not the outside lenders. ${ }^{50}$ Second, once a borrower associates with the main bank within a keiretsu, the information effects of switching banks will impede the borrower's ability to choose a new source of funding. ${ }^{51}$ During the course of developing a client-bank relationship, banks acquire specialized information about their clients, including detailed-and often confidentialinformation about their clients' businesses, localized knowledge about such things as how well their individual clients deal with business problems, and information about whether particular clients are trustworthy. Because this information must be built up over a long period of time through a pattern of

46. See Michael C. Jensen, Takeovers: Their Causes and Consequences, 2 J. EcoN. PERSP. 21, 31 (1988) (stating that hostile takeovers and takeover defenses are funded primarily with debt). The value of debt issued before a takeover reflects the degree of business risk and leverage. Increased leverage (i.e., more debt) results in increased risk to preexisting debt holders. This increased risk causes debt values to decline and equity values to appreciate. See Franco Modigliani \& Merton H. Miller, The Cost of Capital, Corporation Finance and the Theory of Investment, 48 AM. EcoN. REv. 261, 281-88 (1958).

47. MORCK \& NaKAMURA, supra note 28, at 21.

48. Id. at 34 .

49. See note 62 infra and accompanying text.

50. The position of the keiretsu's main bank as de facto insurer for other creditors of keiretsu firms further enhances participant firms' incentive to favor other keiretsu firms over outside lenders. MORCK \& NAKAMURA, supra note 28, at 9-10; Sheard, supra note 29, at 407. Although a keiretsu firm must also consider the interests of its creditors outside the keiretsu, it will often make marginal decisions in favor of the interests of other keiretsu firms and lenders. See Baum \& Schaede, supra note 34, at 642.

51. Monitoring systems in Japanese capital markets are generally underdeveloped, especially when compared to the quality and variety of bond and credit-rating institutions-as well as security analysis agencies - in the United States. Sheard, supra note 29, at 403 . Because of their close, information-sharing relationship with firms, main banks replace other market monitoring mechanisms. Id. 
repeat dealings, the negative market-signaling effect of main bank disassociation heightens the importance of the relationship. ${ }^{52}$ Customers, suppliers, and investors may infer that a client is switching banks because the client is experiencing credit problems. ${ }^{53}$ Because it is expensive to correct this signal, even if the firm's credit is excellent, the firm will avoid main bank disassociation.

Most major Japanese firms are affiliated with main banks. ${ }^{54}$ Managers of these firms sacrifice control and flexibility for the safety and security of a main bank relationship. Over time, Japanese firms become extraordinarily dependent on their banking relationships, relying more heavily on bank debt than American firms. Japanese firms borrow $\$ 5.33$ from banks for every dollar they raise in capital markets, while American firms borrow only $\$ 0.85$ from banks for every dollar they raise in capital markets. 55

This borrowing pattern does not reflect the relative profitability of main bank borrowing. In fact, main banks charge their client firms above-market interest rates, ${ }^{56}$ and the premium over market appears to increase the more the firm becomes dependent upon financing from banks within the keiretsu. ${ }^{57}$ Professor Masahiko Aoki describes the high debt costs as an " 'agency fee' paid by individual stockholders to the bank for [the] service of [monitoring management]." 58 But in light of the embedded conflicts between bank interests and shareholder interests, it is more likely that firms pay these excess fees in exchange for (1) insulating incumbent management of borrower firms from hostile takeovers, and (2) accepting suboptimal returns on their equity holdings.

If banks were acting to maximize equity values in the firms in which they invested, then they would intervene to deter poor stock price performance. Some evidence supports this contention. ${ }^{59}$ Nevertheless, Japanese banks more often interfere in management affairs in response to cash flow and liquidity problems (which are of more concern to banks than the return to equity claim-

52. The information costs that follow disassociation of long-term relationships are by no means limited to Japanese client-bank relationships. In general, moral hazard and adverse selection issues are ameliorated by long-term client-bank relationships. See Douglas W. Diamond, Reputation Acquisition in Debt Markets, 97 J. PoL. Econ. 828, 829 (1989).

53. In addition to indicating significant problems within the firm, disassociation removes the firm from the monitoring function of the main bank.

54. In 1982, over $90 \%$ of the nonfinancial firms listed on the Japanese Stock Exchange were affiliated with a main bank. Sheard, supra note 29 , at 401 .

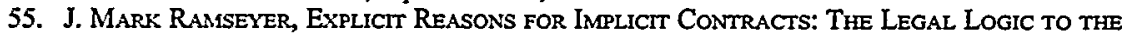
JaPANESE MAIN BANK System 3 (Chicago Working Papers in Law and Economics No. 17, 2d ser., Aug. 1993). Generally, less than half of a Japanese firm's borrowed funds come directly from a main bank. See Toshrirro Horiuch, The Efrect of Firm Status on BankIng Relationshits and Loan SyndiCATTON 20-21, 33 (Università di Siena, Quaderni del Dipartimento di Economia Politica, Apr. 1994). The vast majority of loans to Japanese firms are arranged through loan syndicates which are founded upon the long-term relationship between the firm and its main bank. Id. at 20 .

56. Morck \& Nakamura, supra note 28, at 9 (citing Richard E. Caves \& Masu Uekusa, INDUSTRIAL ORGANIZATION IN JAPAN (1970).

57. Id. Keiretsu firms also tend to have more leverage than unaffiliated Japanese firms, although there are few non-keiretsu firms. Id. This suggests that main banks 'encourage' their keiretsu affiliates to borrow more.

58. Masahiko Aok, Information, Incenttves, and Barganning in the Japanese Economy 148 (1988).

59. See Morck \& Nakamura, supra note 28 , at 30 (concluding that poor cash flows and liquidity problems, as well as poor stock performance, often lead to bank intervention). 
ants) than to poor stock performance. ${ }^{60}$ This strongly suggests that banks do not act altruistically to protect the interests of shareholders, but rather to protect their own interests as fixed claimants. ${ }^{61}$ In fact, contrary to Aoki's assertions, the available evidence indicates that shareholders do not benefit from bank involvement in distressed firms. Although bank involvement improves cash flows and profitability, it has no discernible effect on share prices. ${ }^{62}$ This suggests that managers and bankers, rather than shareholders, consume the value added by banks. ${ }^{63}$

Steven Kaplan and Bernadette Minton also examined the appointment of outside directors to the boards of large nonfinancial Japanese corporations. ${ }^{64}$ Kaplan and Minton observe that outside appointments in the United States are less sensitive to poor corporate performance than in Japan. ${ }^{65}$ Consistent with our view, Japanese banks make more frequent appointments to the boards of keiretsu firms with which they have a significant lending relationship. ${ }^{66} \mathrm{How}$ ever, Kaplan and Minton also find that the appointment of outsiders to Japanese corporate boards is associated with an increase in management turnover. This finding may seem inconsistent with our view that Japanese banks and incumbent management act together to advance the interests of fixed claimants. Kaplan and Minton conclude that their results are

consistent with an important monitoring and disciplining role for banks, corporate shareholders, and corporate groups in Japan. The results are also consistent with the view that the relationship-oriented system of corporate governance in Japan substitutes for the more market-oriented system in the U.S. Banks, corporate shareholders, and corporate groups appear to play a role that is similar to that of takeovers and proxy fights in the U.S. ${ }^{67}$

While Kaplan and Minton persuasively show that Japanese banks monitor and discipline the management of the firms with which they have relationships,

60. Id. at 29. Regression analysis reveals that bank intervention is $100 \%$ more likely when liquidity and cash flows are very low relative to an industry norm than when stock performance is similarly poor. Id.

61. While Japan's banking industry is in financial crisis following the burst of Japan's real estate bubble in 1990, there is no indication that this crisis will provide the impetus for change in banks' interests or investment preferences. Because the losses to Japanese banks followed relatively risky loans in the real estate and financial sectors, keiretsu banks may be more concerned with advancing their interests as fixed claimants and avoiding additional risk in the relatively safe corporate sector. See generally Jean-Michel Paul, Japan's Banking Crisis Continues, WALI Sr. J., June 1, 1995, at A14 (describing the aftermath of Japanese banks' hazardous investment strategy during the 1980s).

62. Following Japanese bank intervention, a firm's liquidity sharply increases, and cash flows return relatively quickly to normal levels. MORCK \& NAKAMuRA, supra note 28, at 36-37. By comparison, although stock return increases $6.4 \%$ on average immediately after intervention, it declines $6.3 \%$ in the year following intervention. Thus, with regard to stock performance, bank intervention is a nearcomplete wash for equity holders. Id. at 34-35.

63. The astonishingly high entertainment expenses incurred by firms subjected to bank intervention further supports this conclusion. In 1991, Japanese corporate entertainment expenses amounted to ¥6.14 trillion ( $\$ 62$ billion). Id. at 34 . In the years immediately following intervention, firm entertainment expenses increased significantly more than $100 \%$. Id. at 57 .

64. Steven N. Kaplan \& Bernadette A. Minton, Appointments of Outsiders to Japanese Boards: Determinants and Implications for Managers, 36 J. FIN. EcoN. 225 (1994).

65. Id. at 239-42.

66. Id. at 243.

67. Id. at 257. 
their analysis fails to show that Japanese banks monitor and discipline the same conduct that the American market for corporate control regulates. In particular, Kaplan and Minton's analysis fails to explain why banks, as fixed claimants, have the same incentive to maximize firm value as equity claimants. Thus, we find their results consistent with our view that Japanese banks discipline and control management teams that endanger the value of the banks' fixed claims. The proposition that Japanese banks have the same preferences as outside equity holders or corporate raiders in the United States is simply without support.

Neither the available evidence nor common sense supports the theory that Japanese main banks altruistically undertake costly monitoring for the principal benefit of shareholders. Rather, the evidence suggests that Japanese banks intervene to protect their own interests as fixed claimants. Because banks are highly leveraged, and demand deposits dominate their balance sheets, banks have a strong incentive to ensure that cash flows from borrowers remain extremely stable. Thus, while Japanese banks hold equity positions in firms to which they loan money, their fixed interests dominate their equity interests.

\section{B. German Universal Banks}

German universal banks play an even greater role in corporate governance than their Japanese counterparts. Indeed, it is no exaggeration to say that "the universal bank sits at the epicenter of German corporate governance."68 As with the Japanese main bank system, scholars tend to romanticize the characteristics and consequences of German corporate governance. ${ }^{69}$ Commentators argue that, in sharp contrast to American banks, German banks have "the position, information, and power to effectively monitor the activity of management and, when necessary, to discipline management." 70 As a result, bank involvement supposedly improves the profitability of firms. ${ }^{71}$

The German Aktiengesellschaft ("AG") is the corporate organizational form most comparable to the American publicly held corporation. ${ }^{72}$ Unlike the American corporation, however, the AG features a two-tier board structure, containing both a management and executive committee (vorstand), and a supervisory board of directors (Aufsichtsrat). ${ }^{73}$ The supervisory board appoints the vorstand, but its other powers are limited: "The supervisory board cannot, even by purported delegation, take any steps in the actual management" of the

68. Gilson \& Kraakman, supra note 1, at 988.

69. See, e.g., John Cable, Capital Market Information and Industrial Performance: The Role of West German Banks, 95 Econ. J., Mar. 1985, at 118, 130 (finding a "significant, positive relationship between the degree of bank involvement" in a firm and its financial performance). But see Roberta Romano, A Cautionary Note on Drawing Lessons from Comparative Corporate Law, 102 YALE L.J. 2021, 2021 (1993) (noting that legal and institutional differences among countries make it difficult to conclude that one country's corporate governance system is superior to another's).

70. Gilson \& Kraakman, supra note 1 , at 988.

71. Cable, supra note 69 , at 121 .

72. See Norbert Horn, Hein Kotz \& Hans G. Leser, German Private and Commercial LAW: AN INTRODUCTION 257-71 (Tony Weir trans., 1982) (describing the legal structure of AG's in Germany).

73. Id. at $258-59$. 
firm, ${ }^{74}$ but it does screen management's investment plans, and it can veto plans of which it disapproves. ${ }^{75}$ One commentator has analogized the role of the supervisory board to that of the U.S. Senate in advising and consenting to the President's appointments and to treaty agreements. ${ }^{76}$

The most striking aspect of the AGs is that fixed claimants, baniks and employees, almost completely dominate the supervisory boards of these firms. Because German banks are heavily represented on the supervisory boards, ${ }^{77}$ and the boards of companies with more than 2000 employees must have employee representation equal to that of the shareholders ${ }^{78}$ the combined power of the fixed claimants dominates the board.

German banks, like Japanese banks, own only a modest share of firms to which they lend money, but they exercise a degree of control significantly greater than their proportionate holdings. Though banks account for only about 6 percent of large share stakes in German firms, ${ }^{79}$ they tend to exert effective control over a majority of the shares voted in annual meetings. ${ }^{80}$ For example, as of 1988 Deutsche Bank and Dresdner Bank directly owned 28.2 percent and 1.6 percent, respectively, of Daimler-Benz's outstanding shares. ${ }^{81}$ By comparison, in 1986 these banks held voting rights in Daimler-Benz of 41.8 percent and 18.78 percent respectively. ${ }^{82}$

The disparity between the small equity positions and the large voting power of German banks is attributable to a combination of three factors. First, German banks vote bearer shares that they hold as custodians for small shareholder-clients of the banks' brokerage operations. These individual investors deposit their shares with banks, and the banks vote by proxy at shareholders' meetings. ${ }^{83}$ Second, German companies frequently pass resolutions capping

74. Id. at 260 .

75. See Julian Franks \& Colin Mayer, Corporate Control: A Synthesis of the International Evidence 11 (Nov. 19, 1992) (unpublished manuscript, on file with the Stanford Law Review).

76. See Roe, supra note 4, at 1942.

77. In 1988, German bank representatives sat on the supervisory boards of 96 of the 100 largest German firms. Roe, supra note 4, at 1939. Bank representatives chaired 14 of those boards. Id.

78. M.C. Oliver, The Private Company IN Germany 12 (1986); Friedrich Kübler, Institutional Owners and Corporate Managers: A German Dilemma, 57 Brook. L. Rev. 97, 98 (1991).

79. Those German Banks and their Industrial Treasuries, EcoNOMIST, Jan. 21, 1995, at 71 (stating that $85 \%$ of Germany's 171 largest nonfinancial firms have single shareholders who own more than $25 \%$ of the voting stock; only $6 \%$ of these large blocs are owned by banks). Ten percent of the total market capitalization is owned directly by banks. Michael Hauck, The Equity Market in Germany and Its Dependency on the System of Old Age Provisions, in InStITUtIONAL INVESTORS AND CoRporate GoverNaNCE, supra note 34 , at 555,561 .

80. Three banks (Deutsche Bank, Dresdner Bank, Commerzbank) controlled an average of $45 \%$ of the voting stock in 32 of the 100 largest AGs in 1986. A combination of eight banks control over $80 \%$ of the voting stock. Amo Gottschalk, Der Stimmrechtseinfluß der Banken in den Aktionärsversammlungen der Großunternehmen, in 5 WSI MTTTEIIUNGEN 294, 298, tbl. 3 (1988).

81. Roe, supra note 4, at 1998.

82. Id. at 1938; Gottschalk, supra note 80 , at 298 , tbl. 3 .

83. When German investors deposit their stock certificates, the custodian bank obtains a revocable proxy authorization from the owner, allowing the bank to vote the stock by "depositary voting right" (Depotstimmrecht). The proxy authorization has a duration of 15 months. AkTENGEsETz [AktG] $\S 135$ (1995) (German Corporate Code). Although depository shareholders do have the right to direct their vote, only about $2-3 \%$ do so. Michael PuRruCKer, Banken IN DER Kartellrechtlichen FusionSKONTROLLE 96 (1983). 
the voting rights of any single shareholder at 5 percent to 15 percent of total votes, regardless of the size of its shareholding. ${ }^{84}$ Because such restrictions do not apply to banks voting shares by proxy, these rules further increase the voting power of the universal banks. ${ }^{85}$ Finally, German banks augment their voting rights by voting the shares owned by mutual funds they operate. ${ }^{86}$

Despite their substantial voting power, German banks' economic stake in AGs is primarily the result of corporate lending. Like Japanese firms, German firms obtain most of their external financing from bank borrowing rather than capital markets. ${ }^{87}$ Bank borrowing, primarily in the form of long-term loans, comprises 20 percent of the external financing for German companies. ${ }^{88} \mathrm{Ger}$ man firms borrow $\$ 4.20$ from banks for every dollar they obtain from capital markets, whereas American firms borrow $\$ 0.85$ for every dollar they raise in the capital markets. ${ }^{89}$

The German bank's dual role as creditor and shareholder creates a significant conflict of interest. Banks have an economic incentive to vote against risktaking at firms to which they have lent money. However, from the perspective of shareholders on whose behalf the banks vote, banks reduce aggregate risktaking to a suboptimal level and thereby transfer wealth from shareholders to themselves. Furthermore, labor interests on the supervisory board are unlikely to oppose banks' efforts to reduce aggregate risktaking because they, too, are fixed claimants, their interests are aligned with those of the bank.

The above description of German corporate governance illustrates that the United States is not the only country to separate corporate ownership and control. As with small U.S. shareholders, individual German shareholders lack "the information, skill, and incentive to monitor managers." 90 The difference appears to be that in America the managers wield the decisive power, while in Germany management shares this power with the banks and labor.

In addition, German banks, like Japanese banks, protect incumbent management by effectively eliminating the market for corporate control. The total number of takeovers in Germany during the 1980s was less than one-half of that in the U.K., and there have only been four recorded cases of hostile takeovers in Germany since World War $\Pi 1 .{ }^{91}$

84. Franks \& Mayer, supra note 75 , at 8 . The corporate charter (Satzung) can be modified by a vote of three-quarters of the shares to limit the voting power of large-block shareholders. AktG $\S 179$ (1995). See Judgment of Dec. 19, 1977, Bundesgerichtshof [BGH], 70 Entscheidungen des Bundesgerichtshofes in Zivilsachen [BGHZ] 117, 121 (German Supreme Court).

85. Gottschalk, supra note 80 , at 294-96.

86. Gilson \& Kraakman, supra note 1, at $987-88$ (noting that German banks' voting control derives from their direct holdings, the proxies they exercise, and their control of mutual funds).

87. The German stock market capitalization is about $25 \%$ of the German GDP, while U.S. stock market capitalization is close to $65 \%$ of the U.S. GDP. See Corporate Governance Survey, supra note 43 , at 6.

88. Cable, supra note 69 , at 119.

89. RAMSEYER, supra note 55 , at 3.

90. Roe, supra note 4, at 1933.

91. Franks \& Mayer, supra note 75, at 8; see also Corporate Governance Survey, supra note 43, at 13 ("There is little prospect of hostile bids coming to ... Germany."). 


\section{Commercial Banks as Fixed Claimants: The Moral Hazard Problem}

It should now be clear that the bank-centered corporate governance structures of Germany and Japan may be more beneficial to commercial banks and to incumbent management than to equity claimants. In this section, we elaborate this argument by examining banks' incentives and transaction costs when making loans to firms. We conclude by demonstrating that although German and Japanese banks are better able to monitor and control moral hazard than American banks, excessive risk-avoidance may effectively prevent the development of robust primary and secondary capital markets.

The economic models of banking recognize that banks face both "adverse selection" and "moral hazard" problems when evaluating the creditworthiness of potential borrowers. In the context of banking, "adverse selection" describes the danger that bad borrowers will seek loans from banks in disproportionate numbers. ${ }^{92}$ This danger exists because bad borrowers have better information regarding their ability to repay loans than their bankers do. Bankers often cannot distinguish between bad borrowers and good borrowers, as all borrowers try to convince lenders that they are good credit risks. Thus, banks conduct costly investigations of potential borrowers to reduce adverse selection costs.

While adverse selection arises at the time a borrower initially applies for a loan, moral hazard problems occur after a bank has extended credit.93 "Moral hazard" refers to the problem that arises when outside equity interests control corporate borrowers' day-to-day operations. Equity investors have an incentive to increase the riskiness of their firms' investments after a bank has extended credit. ${ }^{44}$ As residual claimants, shareholders will receive all the benefits from excess returns associated with these riskier investments, but share any consequent losses with the bank. Thus, borrowers have a strong incentive to increase the riskiness of their firms' projects in order to transfer wealth from the banks to themselves. ${ }^{95}$ Banks can mitigate moral hazard by consistently monitoring borrowers. Repeat dealing further mitigates moral hazard because repeat borrowers realize that banks may terminate credit lines and other lending arrangements upon breach of express or implied conditions in the loan agreements.

92. In the insurance context, by comparison, "adverse selection" results when bad risks purchase insurance because it is underpriced in their view, but good risks do not purchase insurance because it is overpriced from their perspective. ROBERT CoOTER \& THOMAS ULEN, LAw AND ECONOMICs 66-67 (1988).

93. See id. at 65-66 (describing moral hazard problems in the insurance context where the insured's behavior changes after the purchase).

94. See text accompanying note 16 supra.

95. Because American lenders are relatively unable to monitor borrowers' use of the funds, however, they may charge borrowers an inadequate risk premium, creating an inappropriately low capital cost on borrowers' risktaking. By analogy to the relationship between banks and depositors, where the banks are borrowers and depositors are lenders, banks may increase risk without paying higher rates if depositors are poor monitors. George C. Kaufman, The Truth About Bank Runs, in THE FinanclaI Services Revolution: Policy Directions for the Future 9, 23-26 (Catherine England \& Thomas Huertas eds., 1988) (explaining that depositors choose banks less cautiously when their deposits are insured, allowing banks to increase risk without increasing payments to depositors). 
The evaluation process that a firm must undergo before it obtains funds in the capital markets 96 is virtually identical to the evaluation process that a firm undergoes when it applies for a bank loan. The investment banker's scrutiny of the potential issuer, like the commercial loan officer's scrutiny of the potential borrower, is designed to reduce the adverse selection problem that confronts investment bankers and commercial bankers alike. Thus, adverse selection does not explain how the borrower will choose between the debt market and the commercial loan market because neither investment bankers nor commercial lenders have a comparative advantage in solving this problem. Likewise, both have an economic incentive to conduct an extensive evaluation.

Bank lenders, however, do have a comparative advantage over investment bankers in dealing with the moral hazard problem because of the relative lack of a free rider problem in commercial lending. When securities are distributed in a public offering, a shareholder's incentive to monitor the issuer's activities dissipates in direct proportion to the breadth of the distribution. No single investor has sufficient incentive to monitor the activities of the issuer because the monitoring shareholder must share the gains of oversight with all investors, while bearing all the costs. Because a single bank does not face this free rider problem, its monitoring will be more intense than that of multiple investors in a public offering.

This analysis explains why some firms rely more heavily on the bank lending for funds than others. Borrowers presenting more acute moral hazard problems will find it relatively more costly to enter the securities market than the commercial loan market because capital market participants will anticipate the free rider problem and demand additional compensation for accepting the associated risk. ${ }^{97}$ Consequently, firms with acute moral hazard problems will borrow from banks rather than capital market investors. Suppose, for example, that two firms are in need of funding. The first firm's assets cannot be redeployed from their current investment configuration without bankrupting the firm, but the second firm can easily redeploy its assets. The first firm is likely to obtain relatively more of its funding from the securities markets, ${ }^{98}$ while the second is likely to seek the bulk of its funding from banks or finance companies.

96. Section 11(a) of the Securities Act, ch. 38, 48 Stat. 74 (1933) (codified as amended at 15 U.S.C. $\$ 77$ (1994)), provides that any person acquiring a security whose registration statement contains "an untrue statement of a material fact or omit[s] to state a material fact" may sue, among others, every underwriter of the security for damages. $\$ 77 \mathrm{k}(\mathrm{a})$. To avoid liability, the underwriter must show that "he had, after reasonable investigation, reasonable ground to believe and did believe" that the registration statement did not contain an untrue statement or omission. $\S 77 \mathrm{k}(\mathrm{b})(3)(\mathrm{A})$. The investigation and review of the registration statement prompted by these sections is known as "due diligence."

97. For example, the high fixed costs of public offerings preclude many smaller firms from entering the public markets for debt and equity. See Jonathan R. Macey, Administrative Agency Obsolescence and Interest Group Formation: A Case Study of the SEC at Sixty, 15 CARDOzo L. REv. 909, 925 (1994) (arguing that the rules of capital formation and allocation increase the cost of raising capital).

98. This is a generalization, absent considerations of leverage and optimal capital structure. Broadly, this assertion is correct, at least for medium and large firms, because their marginal fixed costs of an equity issue will be less than the marginal costs associated with borrowing. 
Generally, when information about assets is readily available, those assets will be securitized. ${ }^{99}$ Conceptually, the credit risks posed by firms occupy points on "a continuum, with 'information-problematic' borrowers at one end, and borrowers with few information problems at the other." 100 Borrowers with few information problems will issue publicly traded securities (along with commercial paper and medium term notes) and forego bank borrowing. ${ }^{101}$ Information-problematic borrowers, however, must obtain financing from banks or finance companies because capital market participants will be unwilling to extend credit to issuers about whom they have insufficient information. ${ }^{102}$

While commercial lenders have no ex ante advantage over other financial intermediaries in terms of obtaining information about borrowers, ${ }^{103}$ they have an ex post advantage in their ability to monitor and control borrowers after the lending decision has been made. This ability to control borrowers and thereby reduce moral hazard is the source of commercial lenders' advantage over the capital markets.

Our account differs from conventional analysis in two ways. First, we distinguish between information that relates to the borrower ex ante (i.e. before the decision to extend credit is made) and information about the borrower ex post (i.e. after the decision to extend credit has been made). It is a lender's ability to gain access to information ex post that distinguishes lending from securitization. Second, we stress that having few information problems is a necessary, but insufficient, condition for borrowers to enter the capital markets. Potential borrowers also must make a credible commitment that the nature of the information will not change ex post. For this to happen, the lender will find it necessary to retain significant control or potential control over the borrower ex post. This degree of control differentiates a typical lending relationship from a securities offering.

99. Alan Greenspan, Statement before the Committee on Banking, Housing, and Urban Affairs, U.S. Senate (Dec. 1, 1987), 74 FED. RESERVE Bulc. 91, 94 (1988) (discussing advancing technology that provides investors with access to monitoring information that only depository intermediaries previously possessed); see also Jonathan R. Macey \& Geoffrey P. Miller, Bank Failure: The Politicization of a Social Problem, 45 Stan. L. Rev. 289, 296-97 (1992) (asserting that information costs decline with advancing technology, allowing assets about which information is scarce to be securitized).

100. Macey \& Miller, supra note 99, at 296 (arguing that securitization has caused banks to take on a greater portion of risky, information-problematic credit risks, resulting in an increasingly risky commercial banking industry); see generally ROBERT E. LITAN, What SHOULD BANKS Do? 8-10 (1987) (describing financial intermediaries' traditional role of assuming the risk of mismatched savers and investors).

101. Macey \& Miller, supra note 99, at 296; see also Douglas W. Diamond, Debt Maturity Structure and Liquidity Risk, 106 Q. J. Econ. 709, 709 (1991) (developing a model to explain why firms with high credit ratings issue short-term debt while firms with low credit ratings issue long-term bonds or borrow from financial intermediaries).

102. Macey \& Miller, supra note 99 , at 296. As informational distinctions blur, they lose relevance to the structure of firm financing. The recent growth in the structured finance industry, for example, allows a firm with aggregate information problems to separate assets which are not informationproblematic from those which are. Investors then look only to the separated assets, not the informationproblematic firm, for payment. See Steven L. Schwarcz, Structured Finance: A Guide to the FUNDAMENTALS OF ASSET SECURITIZATION 1-3 (1990) (potential buyers of the securities look to the cash flow from the purchased receivables, and not to the credit of the selling company).

103. See Greenspan, supra note 99 , at 93-94. 
Combining the deposit-taking function and the lending function within a single firm enables banks to obtain reliable information about the investment decisions of corporate borrowers. ${ }^{104}$ Deposit taking provides banks with an important source of information about borrowers because banks generally make loans to clients who maintain other accounts with the bank. The information that banks derive from monitoring commercial customers' checking accounts, for example, gives them a significant information advantage over other financial intermediaries. ${ }^{105}$ Under this "checking account hypothesis," banks are good monitors of borrowers because of their exclusive access to current information concerning the ongoing financial condition of borrowers. ${ }^{106}$

Unfortunately for commercial banks, technological advances have reduced the costs of recording, transmitting and processing customer information. ${ }^{107}$ In the United States, these advances have made it possible for nonbank lenders such as commercial finance companies to obtain the information they need about borrowers without offering checking accounts. ${ }^{108}$ Computer-based retail information services, for example, provide lenders with detailed data about the cash flows and inventories of borrowers. ${ }^{109}$ Such information is often more current than that available from checking account records. ${ }^{110}$

To successfully avoid the costs of moral hazard, banks must have not only information about their borrowers, but also the ability to use this information to control their borrowers. Lenders do this in three important ways:

First, lenders traditionally execute detailed loan documents that enable them to call their loans if the borrower violates the loan's terms and conditions. ${ }^{111}$ These documents also typically give the lender access to confidential information about the borrower.

Second, banks tend to keep loan maturities relátively short and to require borrowers to rely on revolving lines of credit. ${ }^{112}$ This places borrowers in a

104. Leonard I. Nakamura, Commercial Bank Information: Implications for the Structure of Banking, in Structural Change in Banknng 131, 135-36 (Michael Klausner \& Lawrence J. White eds., 1993) (illustrating the advantages of combining the deposit-taking function with the lending function).

105. Macey \& Miller, supra note 99 , at 295.

106. Id. at 294-95; see also Nakamura, supra note 104, at 133 (asserting that banks have a "safe clear edge" over nonbank lenders because of checking accounts).

107. Greenspan, supra note 99, at 93-94.

108. See id.

109. See Macey \& Miller, supra note 99 , at 295.

110. See Jonathan R. Macey, The Inevitability of Universal Banking, 19 BrooK. J. INr't L. 203, 214-15 (1993) (noting that technological advances now permit lenders to monitor borrowers' inventory and receivables status almost as soon as transactions between borrowers and their customers are completed).

111. There are four types of loan covenants which mitigate the information/control dilemma: (1) covenants that restrict the use of funds, (2) covenants that specify that firms must maintain a certain net worth, (3) covenants that restrict the use and maintenance of collateral, and (4) covenants that require the borrower to provide the lender with periodic information. FrEDERIC S. MISHKIN, THE ECONOMICS OF MONEY, BankING, AND Financial Markets 221-22 (4th ed. 1995).

112. See Douglas W. Diamond, Monitoring and Reputation: The Choice Between Bank Loans and Directly Placed Debt, 99 J. Pol. Econ. 689, 689-91 (1991). Borrowers necessarily accept this termstructure, because lenders will provide long-term credit only if the borrower has a good reputation, or develops one through a succession of transactions with the lender. See id. at 691 . On the other hand, highly rated borrowers generally prefer short-term credit, because this allows them to respond to market- 
pattern of repeat dealings with particular banks, giving borrowers a strong incentive to refrain from moral hazard. The implicit information sent to the market by a borrower's switch in allegiance is a great disincentive to borrower migration. The constraints forced upon borrowers by long-term lending relationships explain why commercial paper has become a direct substitute for bank lending in the United States. 113 Investment banks have captured a large portion of the commercial lending business of the nation's commercial banks by replacing commercial borrowing with the sale of commercial paper. ${ }^{114}$ The short-term maturity structure of commercial paper makes it virually impossible for an issuing company to succumb to the moral hazard of increasing the volatility (riskiness) of its expected returns after the securities have been issued and before they mature.

Finally, in jurisdictions where it is legally permissible, such as Germany and Japan, lenders control borrowers directly by purchasing equity positions and thereby obtaining representation on corporate boards of directors. ${ }^{115}$ These activities reduce moral hazard not only by giving banks access to privileged information about borrowers, but also by giving them greater influence and control over the activities of their borrowers. Through their voting rights, for example, German and Japanese banks can control firms' access to external sources of funds, preventing them from obtaining financing to engage in risky investments.

This explains why it is in the bank's interest (although perhaps not in the interest of the firm's equity investors) for a bank simultaneously to lend money to, and buy equity in, the same firm. The equity investments reduce the adverse selection problem by providing banks with access to positions on corporate boards, which, in turn, gives them access to information about the creditworthiness of their clients. Additionally, banks' equity investments mitigate the moral hazard problem both by giving banks a significant measure of control

place changes more readily. See Diamond, supra note 101, at 710 . This is not the case with risky borrowers, who prefer long-term debt in order to increase their liquidity. See id. These observations indicate that the interests of lenders and borrowers differ, except in the case of highly rated firms with well-established reputations. These firms, however, have a significantly greater preference for the capital markets, since they are the least information-problematic. Risky firms, by contrast, submit to bank control and monitoring in order to resolve interest conflicts and to establish a good reputation.

113. The term "commercial paper" means the publicly issued short-term promissory notes of industrial companies (generally 90 days or less).

114. Jonathan R. Macey \& Geoffrey P. Miller, America's Banking System: The Origins and Future of the Current Crisis, 69 WASH. U. L.Q. 769, 775-76 (1991). Commercial paper is attractive to issuers "because it provides ready access to capital, does not create long term financial obligations, and does not require extensive and costly negotiations prior to issuance." Id. at 776; see also David G. Litt, Jonathan R. Macey, Geoffrey P. Miller \& Edward L. Rubin, Politics, Bureaucracies, and Financial Markets: Bank Entry into Commercial Paper Underwriting in the United States and Japan, 139 U. PA. L. REv. 369, 375 (1990).

115. In the United States, sections 16 and 5(c) of the Banking Act of 1933 (Glass-Steagall), ch. 89,48 Stat. 162 (1933), generally prohibit national banks and state-chartered banks that are members of the Federal Reserve System from owning equity securities. 12 U.S.C. $\$ \S 24,335$ (1994); see also Jonathan R. Macey \& Geoffrey P. Miller, Bankng Law and Regulation 175-178, 497 (1992) (discussing both the general rule against owning equity securities and various exceptions to the rule); Mark J. Roe, A Political Theory of American Corporate Finance, 91 Colum. L. REv. 10, 17 (1991) (explaining the evolution of the rule against owning equity). 
over their borrowers, and by securing some of the upside associated with their borrowers' risky projects. But banks' highly leveraged capital structure, combined with their usual liquidity needs (arising because of the large proportion of their liabilities composed of demand deposits), ensures that commercial banks' incentives as fixed claimants will dwarf their interests as residual claimants. Thus, they will prefer steady investment returns over highly volatile ones. ${ }^{116}$

The Coase Theorem implies, however, that absent transaction costs, banks as fixed claimants and nonbank equity holders could settle any conflicts by bargaining. ${ }^{117}$ Applying Coase's theorem to the commercial banking context, banks would not block positive present value projects, or prevent shareholders from engaging in risky projects that they prefer. Instead they would bargain to be compensated for bearing additional risk, and the projects would go forward.

A simple numerical example illustrates Coase's point. Imagine a firm with only two classes of claimants, a bank with fixed claims of $\$ 80$ and shareholders with equity claims of $\$ 20$. Suppose further that the firm has the opportunity to undertake a project that would raise its overall value from $\$ 100$ to $\$ 105$. The bank would block the project if the equity claims were expected to increase in value from $\$ 20$ to $\$ 26$ but the fixed claims were expected to decrease in value from $\$ 80$ to $\$ 79$. If the shareholders agreed to give the bank $\$ 3$ of their $\$ 6$ gain, both the fixed claimant and the equity claimants would be better off if the project went forward. ${ }^{118}$

Unfortunately, in the German and Japanese contexts, several factors prevent banks and equity claimants from reaching efficient bargaining solutions. First, German and Japanese banks justify their role in their respective corporate governance systems on the ground that they benefit the firms with which they are so intimately involved. Indeed, German banks owe a fiduciary duty to the shareholders whose shares they hold in trust. For banks to bargain in the manner described above, they would have to threaten to refuse to maximize firm value unless the shareholders agreed to share their equity gains. This sort of bargaining would unmask serious problems with the Japanese keiretsu system and the German universal bank system and expose banks to serious charges of extortion.

A second, more fundamental obstacle to efficient bargaining stems from the incompatible risk preferences of bank and nonbank equity holders. Banks prefer safety for two reasons: their highly leveraged capital structures and their undiversified human capital investments in the firms with which they have relationships. Higher present-value projects are riskier and banks prefer to avoid this additional risk. Banks' highly leveraged capital structure makes these additional risks appear even less attractive. Even considering potential side pay-

116. See MACEY \& MILLER, supra note 115, at 56-59 (discussing the concept of leverage generally, and the influence of a bank's high leverage on its capital structure strategies).

117. In the absence of impediments to bargaining (transaction costs), private contractual arrangements among parties will produce efficient outcomes. R.H. Coase, The Problem of Social Cost, 3 J.L. \& ECoN. 1 (1960).

118. In this example, the shareholders' claims would rise in value from $\$ 20$ to $\$ 23$ and the bank's claim would rise in value from $\$ 80$ to $\$ 82$. 
ments, banks' expected utility loss on the downside exceeds their expected utility gain on the upside.

Agency costs and collective action problems present further impediments to bargaining between bank and nonbank equity holders. Inside managers, who are also fixed claimants, typically identify the firms' new projects. Outside equity holders are widely dispersed and have no way of knowing about, much less bargaining over, prospective new ventures. Thus, while German and Japanese banks have the incentive and the means to control moral hazard problems, German and Japanese outside equity holders have no way to bring their preferences to the bargaining table.

Finally, of course, German and Japanese bankers are imperfect agents of their own shareholders. As fixed claimants of the banks' assets, bankers may prefer not to maximize their institutions' profits, if doing so would require them to assume risks for which they would not be fully compensated.

Given their capacity to control adverse selection and moral hazard problems, however, one might expect German and Japanese banks to be more successful than American banks, and to play a correspondingly larger role in their respective economies. German and Japanese banks' comparative superiority in controlling moral hazard reduces the banks' aggregate risk, which contributes to greater profitability. Moreover, these banks' superior ability to control moral hazard suggests that, at the margin, German and Japanese firms would find bank financing relatively more attractive than capital-market financing. As banks exert greater control over firms, the cost of raising equity capital adjusts upward to reflect the high risk-aversion costs caused by banks' domination of the money markets.

\section{BANKS VERSUS THE ECONOMY}

While placing banks in positions of exceptional power over their borrowers may be optimal for banks, it may not be optimal for the rest of society. Because fixed claimants, such as banks, have no incentive to see that all their borrowers' positive present value projects are approved, granting banks a critical role in corporate governance can result in allocative inefficiency. Suppose, for example, that a German firm faces an investment with positive present value but very high risk. This investment will raise the price of the equity shares by $\$ 10$ per share, for a total increase of $\$ 100$ million. The riskiness of the project, however, will reduce the value of fixed claims by $\$ 10$ million. Clearly, the firm should undertake the project because the benefits significantly outweigh the costs. But if, as in Germany, the firm's banks (in collaboration with workers, managers and other fixed claimants) dominate the decision-making process, then they are likely to veto the project because their fixed claims would lose more value than their equity claims would gain.

The German and Japanese systems of strong banks and bank-dominated corporate governance structures cannot be defended as efficient on the grounds that these systems are the result of market forces. Like the American system, 
politics, social trends, and historical happenstance played a major role in the development of the German and Japanese systems. As Mark Roe has observed:

In Germany, the banks captured the securities channel; the German securities market is weak, and the banks substantially control it, a result that allows for powerful [banks]....

....

... Japanese postwar regulation skewed industry financing toward banks and away from the securities market by: (1) suppressing the bond market through collateralization and issuance regulations; (2) limiting competing sources of corporate finance, such as equity issuance; (3) impeding the development of investment companies; (4) requiring that banks serve as trustees for bondholders when companies were allowed access to the bond market; and (5) holding down the interest rates paid on deposits to enable banks to profit even when lending at low rates. ${ }^{119}$

The bank-dominated corporate governance structures heralded by American commentators as a viable alternative to the Berle-Means corporation may in fact provide private advaritages to the banks themselves, while creating ineffciencies for society as a whole. The informational advantages inherent in German banks' domination of the shareholder voting process and control over the supervisory boards of directors may account for some of their extraordinary success.

After correcting for differences in GNP growth, German banks have grown twice as fast as U.K. banks, and 1.5 times as fast as U.S. banks during the past twenty years. ${ }^{120}$ Moreover, German banks' enhanced ability to monitor borrowers appears to make lending attractive relative to financing in that nation's capital markets. Over the past 20 years, while American corporations have obtained more financing from debt securities than from bank loans, German firms have raised about twice as much with bank loans as they have from debt

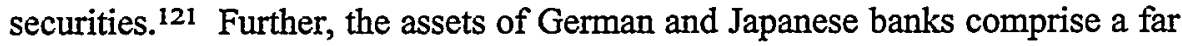
greater percentage of their respective gross national products than the assets of American banks do in the United States. Bank sector assets comprise 146 percent of German GNP and 167 percent of Japanese GNP, but only 62 percent of American GNP.122 Finally, the real rate of return on equity for American banks is just over one-half that of German banks and only one-third that of Japanese banks. ${ }^{123}$

As banks in Germany and Japan remain strong, banks in the United States are getting weaker. In recent years, the importance of American banks in the capital market has further declined. Depository institutions, for example, held

119. Roe, supra note 4, at 1955 (citations omitted).

120. Competition in Banking. NEwsL. London Bus. Sch. INST. Fin. \& Acct., Winter 1992-93, at 6 (summarizing an address by Robert Glauber, former U.S. Treasury Under Secretary).

121. Id.

122. Roe, supra note 4, at 1999 tbl. IX (based on 1991 data).

123. SaUnders \& WaLter, supra note 9 , at $22-23$, tbl. $2-1$ (based on a study by the Federal Reserve Bank of New York of 51 banks that were internationally active during the second half of the 1980s). The real asset growth of German banks was three times that of American banks. Japanese banks' real assets grew by nearly seven times those of American banks. Id. 
57 percent of U.S. financial sector assets in 1978, but only 33 percent in 1991.124 Meanwhile, mutual funds and pension funds increased their market share from 11 percent to 25 percent. ${ }^{125}$ On the asset side, commercial paper underwritten by investment banks came to be seen by the largest, highest quality borrowers as a superior alternative to bank loans. In 1991, nonfinancial corporations raised $\$ 107$ billion from commercial paper, all of which would have been funded through bank borrowing only a decade before. ${ }^{126}$ Moreover, finance companies that are funded with commercial paper have begun to compete with banks. By the end of 1991, finance companies had $\$ 315$ billion in loans outstanding to American businesses. ${ }^{127}$ This figure is almost one-half of the $\$ 650$ billion in commercial loans outstanding at that time. ${ }^{128}$

The story from America is clear. Technological changes and changes in underlying market conditions have caused a systematic diminution in the demand for banks' services. Services that once were performed by banks now are routinely provided by other sorts of firms in the United States. The problem for American banks is that they do not have the same informational advantage over other financial intermediaries as German and Japanese banks enjoy.

Banks' ability to earn a profit on the spread between their cost of funds and their return on assets results from their ability to process information about credit risk better than other types of financial intermediaries. As Alan Greenspan has observed:

The heart of financial intermediation is the ability to obtain and use information. The high cost of gathering and using facts in the past meant that banks and other intermediaries could profit from their cumulative store of knowledge about borrowers by making significantly more informed credit decisions than most other market participants. These other market participants were thus obliged to permit depository intermediaries to make credit decisions in financial markets and therefore allow bank credit to substitute for what would otherwise be their own direct acquisition of credit market instruments. ${ }^{129}$

In the United States, however, the advance of computer and telecommunications technology has dramatically reduced the costs of recording, transmitting, and processing this information. These technological advances have allowed firms in need of capital to bypass commercial banks and to enter the capital market for funds. For borrowers, "[o]n-line data bases, coupled with powerful computers and wide-ranging telecommunication facilities, can now provide potential investors with virtually the same timely credit and market information that was once available only to [banks]."130

Beyond the decline in demand for banks' asset-valuation skills, changing U.S. financial markets have provided alternative vehicles for raising capital and

124. Competition in Banking, supra note 120 , at 4.

125. Id.

126. Id.

127. Id.

128. Id.

129. Greenspan, supra note 99 , at 93 .

130. Id. 
securing credit-both services traditionally supplied by banks. In particular, the development of secondary and new issues markets for trading securities has made it increasingly easy for business firms to raise capital through public offerings of securities or securitization. Other alternative financial mechanisms for raising capital in the United States that have displaced banks include: mortgage-based securities, consumer receivables financing, consumer loan-based securities, and commercial paper. ${ }^{131}$

The steady decline in American commercial banks' overall share of the financial markets has not been distributed evenly over their assets. Rather, securitization has replaced the best assets on banks' balance sheets, resulting in an increasingly risky American banking industry. As noted above, the distinctive characteristic of commercial banks is that they specialize in analyzing and holding nonstandardized or "information-problematic" credit risks in their portfolios. ${ }^{132}$ Typically, borrowers with few information problems will not use bank borrowing as much as other firms but instead will issue traded securities, along with commercial paper and medium-term notes-all of which are more economical than bank borrowing. ${ }^{133}$ But because capital market participants are less willing to extend credit to issuers about whom the market has little knowledge, information-problematic borrowers frequently must turn to more expensive commercial loans from specialized depository institutions.

Over time, the ability of American security markets to process information has improved. Assets once considered opaque to market analysts and thus not securitizable (like credit card receivables and home mortgages) can now easily be securitized. ${ }^{134}$ Assets that are extremely difficult to analyze, and thus cannot be easily securitized, are kept on banks' balance sheets. Thus, banks that once held a balanced mix of safe and risky assets are finding themselves stuck with only risky, information-problematic assets. ${ }^{135}$ American banks essentially are left with a simple choice-shrink, or become riskier:

As assets that are more easily susceptible to monitoring are stripped out of banks' assets and securitized, banks are faced with the following choice: they can either shrink by declining to replace securitized assets with new assets, or else they can ... make loans to borrowers with more severe information problems than previously had been made. ${ }^{136}$

131. Greenspan, supra note 99 , at 94 .

132. Miller \& Macey, supra note 99, at 296; see also Litan, supra note 100, at 8-10 (describing how dealers and brokers match savers and investors directly, while financial intermediaries assume the risk of an imperfect match).

133. Miller \& Macey, supra note 99 , at 296-97.

134. Id.; see also Schwarcz, supra note 102, at 4 (examples of securitized assets include mortgage loans, trade receivables, and credit card receivables).

135. Macey \& Miller, supra note 99, at 296; see also Tamar Frankel, Securmization: Structured Finance, Fndanclal Asset Pools, ANd Asset-Backed Securutres § 4.9 (1994) (arguing that generally, the best borrowers have left banks for financing in secondary markets and thus banks must compete for borrowers who cannot resort to those markets).

136. MACEY \& MRLER, supra note 115, at 297. 


\section{IMPLICATIONS For AMERICAN CORPORATE GOVERNANCE}

We wish to stress that our point is not that the American system of corporate governance is superior to its German and Japanese counterparts. Our point is merely to show that the supposed advantages of the German and Japanese systems have been exaggerated, while the costs have been underemphasized. These costs come not only in the form of excessive risk aversion, which leads to a stifling of innovation, but also manifest themselves in the form of illiquid, undeveloped, and poorly functioning capital markets.

For several reasons, German and Japanese capital market participants have fewer incentives than similarly situated Americans. First, German and Japanese banks reduce the potential gain from investing in the stock market by limiting upside gains to residual claimants. Second, the highly concentrated patterns of share ownership in Germany and Japan have made hostile takeovers, a major source of potential gains for target company shareholders, practically impossible for most insurgent groups to mount successfully. Third, these concentrated patterns of share ownership also reduce order flow in the market, thereby depriving it of liquidity. Finally, and perhaps most important, the core purpose of the German and Japanese corporate governance systems has been to produce stability for systems which were characterized by massive uncertainty in the immediate post-war period. ${ }^{137}$ But there is growing evidence that this kind of stability is not a virtue today, with global competition and rapid technological innovation placing a far higher premium on innovation and flexibility than on stability.

For purposes of comparing the American system of corporate governance with the Japanese and German systems described above, we focus in this section on three sets of problems existing within the American system. The first is the possibility of excessive risktaking. Just as the German and Japanese bankdominated systems described above may cause firms to forsake potentially profitable projects that appear too risky to them, the American system may cause firms to undertake excessively risky projects because weak banks in the United States are unable to monitor and control excessive risktaking as effectively as German and Japanese banks do. The second consideration is the declining capacity of market forces to discipline managers and improve corporate performance in the American system. In recent years, politics increasingly has interfered with the functioning of the market. In particular, politics has reduced the efficacy of the market for corporate control, which is the central device for disciplining managers in market-oriented corporate governance systems such as those in the United States and Britain. Finally, a set of seemingly minor rules in the United States artificially impedes the ability of fixed claimants to monitor and control borrowers. Thus, while the level of control observed in the

137. This is especially true in post-war Japan, MorCK \& NAKAMurA, supra note 28 , at 6 , despite the post-war efforts of the occupation forces. Roe, supra note 4, at 1972. Germany, which has relied heavily on central banks since Bismarck, naturally looked to central banks as sources of economic stability after the Second World War. See id. at 1971. 
Japanese and German bank-dominated systems probably is too high, the level of bank control in the American system probably is artificially low.

\section{A. The Problem of Excessive Risktaking}

Just as fixed claimants can transfer wealth to themselves from equity claimants by reducing a firm's riskiness ex post (i.e., after a firm's capital structure has been determined), so too may equity claimants increase their own wealth at the expense of the fixed claimants by increasing the firm's riskiness. ${ }^{138}$ In a properly functioning corporate governance structure, the fixed claimants and the shareholders will reach the appropriate bargaining equilibrium between the risk-preferring proclivities of the shareholders and the risk-averse proclivities of the fixed claimants.

Several features of the American corporate governance system prevent shareholders from acting opportunistically through increased risktaking. First, fixed claimants may protect themselves against this contingency contractually. ${ }^{139}$ Second, American banks often make loans with relatively short maturities, thereby forcing borrowers to rely on revolving lines of credit. Because borrowers realize that they must obtain bank approval for additional credit when their loans reach maturity, banks gain leverage over borrowers through repeat dealings. Third, by buying convertible bonds (convertible into equity claims), fixed claimants may reduce borrowers' incentives to engage in excessive risktaking because borrowers know that the bondholders are first in line for repayment in the event of default. If the shareholders' risky investments are successful, however, convertible bondholders convert their fixed claims into equity and share in the upside. Fourth, because American shareholders are generally widely dispersed - each owning only a tiny fraction of a company's outstanding shares-they have little incentive to monitor managers and are largely subject to managers' risk preferences. Because managers are averse to the high levels of risktaking shareholders prefer, this agency cost helps other fixed claimants such as banks. For these reasons, the danger that American firms will engage in excessive risktaking appears relatively small compared to the danger that Japanese and German firms will avoid socially efficient risks.

\section{B. The Market for Corporate Control}

The market for corporate control lies at the heart of the American system of corporate governance. Hostile bidders target poorly performing firms and replace their inadequate or shirking managers with rival management teams. ${ }^{140}$

138. See Porter, supra note 5, at 67 ("The U.S. system first and foremost advances the goals of shareholders interested in near-term appreciation of their shares-even at the expense of the long-term performance of American companies.").

139. See note 111 supra and accompanying text; Clifford W. Smith, Jr. \& Jerold B. Warner, On Financial Contracting: An Analysis of Bond Covenants, 7 J. Fin. Econ. 117, 124-26 (1979) (describing various contractual mechanisms used by fixed claimants to control shareholders).

140. See Roberta Romano, A Guide to Takeovers: Theory, Evidence, and Regulation, 9 Yale J. ON REG. 119, 129-31 (1992) (describing takeovers as a backstop mechanism for monitoring performance when other corporate governance devices fail). 
Between 1985 and 1990, hostile takeovers accounted for $\$ 140$ billion in U.S. financial transactions. ${ }^{141}$ Moreover, innovations in corporate finance, such as bridge financing and junk bonds, created a competitive environment in which virtually every firm was a potential takeover target. The frequency of hostile takeovers increased managerial efficiency, as high share price is considered the strongest hostile takeover defense. ${ }^{142}$

Contrary to critics' claims, studies show that hostile takeovers do not lead to massive layoffs. ${ }^{143}$ Indeed most blue collar workers retain their jobs after hostile takeovers. The layoffs occur among middle managers, who usually find replacement jobs surprisingly quickly. ${ }^{144}$

Available evidence also refutes the hypothesis that hostile takeovers are undesirable because they induce managers to focus too much on short-term share prices to the detriment of long-term corporate performance. Share prices set by capital markets reflect the present value of corporations' expected future returns. Thus, firms investing in research and development ("R\&D") and other long-term projects will not suffer from lower share prices and increased chances of hostile acquisition because their share prices will adjust to reflect the future payoffs of investments in R\&D. ${ }^{145}$ Thus, it is unsurprising that hostile acquirors rarely slash R\&D investments in acquired firms. Similarly, firms with heavy R\&D investments are less likely to be subjects of hostile takeovers than are other firms. ${ }^{146}$

American corporations are not beleaguered by too many hostile takeovers; rather, regulatory restrictions and misguided legal policies stifle the market's demand for hostile takeovers, thereby limiting their number. The number of hostile takeovers in the United States declined precipitously from a high of forty-six in 1988 to only two in 1991. 147 State antitakeover laws are more prevalent and increasingly prohibitive, a testament to management's political

141. Corporate Governance Survey, supra note 43, at 6.

142. High share prices make takeovers prohibitively expensive. See Frank H. Easterbrook \& Daniel R. Fischel, The Proper Role of a Target's Management in Responding to a Tender Offer, 94 HARV. L. REv. 1161, 1174 (1981) ("Managers will attempt to reduce agency costs in order to reduce the chance of takeover, and the process of reducing agency costs leads to higher prices for shares."); see also Daniel R. Fischel, The Corporate Governance Movement, 35 VAND. L. REv. 1259, 1264 (1982) (arguing that the market for corporate control "simultaneously gives managers of all firms who wish to avoid a takeover an incentive to operate efficiently and to keep share prices high").

143. Romano, supra note 140 , at 172.

144. Id.

145. Jonathan R. Macey, State Anti-Takeover Legislation and the National Economy, 1988 Wis. L. REv. $467,479-82$.

146. Id, at 482 .

147. Marcel Kahan \& Michael Klausner, Antitakeover Provisions in Bonds: Bondholder Protection or Management Entrenchment?, 40 UCLA L. REv. 931,979 (1993). In the first quarter of 1995, however, mergers and acquisitions in the United States reached $\$ 73.2$ billion, the highest first-quarter level since 1989. Steven Lipin, Mergers and Acquisitions in Ist Quarter Increased 35\% from the Year Before, Wall ST. J., Apr. 4, 1995, at A3. Recent mergers and acquisitions in the United States do not appear to be directed at ousting inefficient management, but rather to achieving synergistic gains through economies of scale or scope in operations. Some acquisitions may be designed to increase the acquiror's market share, rather than to benefit from improving the target's performance. See Greg Steinmetz, Mergers and Acquisitions Set Records, But Activity Lacked that 80 s Pizazz, Wall St. J., Jan. 3,1995 , at R8. 
acumen in dealing with state legislatures at the expense of out-of-state shareholders. ${ }^{148}$ In fact, one of the worst consequences of America's widely dispersed share ownership is shareholders' inability to form effective political coalitions to block management's political mobilization against hostile takeovers. Political maneuvering, for example, culminated in the Pennsylvania's 1990 antitakeover law, which represents a massive wealth transfer from shareholders to incumbent management. ${ }^{149}$

In addition to antitakeover laws, incumbent management has successfully persuaded state legislatures to pass so-called "other constituency" statutes. These statutes empower corporate management to consider the interests of employees, local communities, suppliers, and customers when deciding whether and how to resist a hostile takeover. ${ }^{150}$ These thinly disguised efforts to advance management interests at the expense of shareholders permit managers to defend themselves against shareholders' lawsuits after adopting defensive tactics to entrench themselves in office. ${ }^{51}$ Pursuant to these statutes, managers may mount credible arguments that their resistance to takeovers furthers the interests of some nonshareholder constituency or other, thus giving courts a legal hook upon which to hang their decisions favoring incumbent management.

State court judges have provided little, if any, comfort to shareholders. In particular, they have done little to curb the use of antitakeover devices, such as the poison pill, which may be adopted by a target company's board of directors without a shareholder vote. 152 In December 1993, however, the Delaware Supreme Court prevented Paramount from using its poison pill to foil a hostile takeover by QVC. ${ }^{153}$ This decision may prompt other American courts to look more favorably upon outside shareholders' interests which, in turn, could usher in a new era of hostile takeovers in the United States.

One legitimate complaint against hostile takeovers as a corporate governance mechanism is that "companies have to go further off course before attracting a hostile bid than they might if managers were monitored continuously." 154 Hostile bids are extremely capital intensive, not only because they require major financing commitments, but also because bidders must invest a substantial amount of resources in research to identify undervalued targets before ever making a takeover bid. Unless a firm is substantially undervalued, bidders will be unable to recoup these capital and search costs.

148. Macey, supra note 145 , at $468-70$.

149. See Act of Apr. 27, 1990, P.L. 129, 1990 Pa. Laws 36 (codified in scattered sections of 15 Pa. Cons. Stat.). Pennsylvania's antitakeover rules are "more extreme than those of any other state." William A. Kledn \& J. Mark Ramseyer, Cases and Materials on Business associations: Agency, Partnerships, AND Corporations 819 (2d ed. 1994).

150. Macey, supra note 145 , at 469 .

151. The statutes also advance management interests at the expense of employees. See Romano, supra note 140, at 171-73.

152. See Denns J. Block, Nancy E. Barton \& Stephen A. Radin, The Business Judgment Rule: Fiductary Duties of Corporate Directors 233-37 (4th ed. 1993).

153. Paramount Communications v. QVC Network, Inc., 637 A.2d 34 (Del. 1994).

154. Corporate Governance Survey, supra note 43 , at 13. 
For at least three reasons, however, this flaw in the corporate control market does not disadvantage the American system of corporate governance relative to the German and Japanese systems. First, it does not really distinguish the American system of corporate governance from its German and Japanese counterparts. Like American corporations, German and Japanese firms must go substantially off course before attracting outside intervention. As fixed claimants, German and Japanese banks are unconcerned with small deviations from optimal performance levels that do not threaten their return on capital.

A second problem with criticizing the takeover market as too costly is that the market for corporate control affects managerial performance even in the absence of a formally announced takeover bid. A robust market for corporate control improves management's performance because incumbents inevitably prefer to reduce the probability that an outside bid will be made. Incumbent management will be unsure how much better a particular rival management team is; consequently, management will be unsure how far the firm's share price must fall before attracting a hostile bid. This uncertainty creates an incentive for managers to improve the firm's performance, even if a hostile offer never actually materializes. ${ }^{155}$

Finally, commentators who argue that takeovers are too expensive erroneously conceptualize takeovers as an all-or-nothing proposition. Investors need not launch a full-blown tender offer to put a target company effectively in play. Through a proxy contest, for example, investors may launch a takeover for as little as $\$ 5000$ (down from $\$ 1$ million a few years ago). ${ }^{156}$ Similarly, institutional investors often purchase large stakes in troubled firms, then use their votes to install directors on corporate boards to "agitate for better performance."157 To exploit these strategies such that management improves, potential insurgents must present a credible threat. ${ }^{158}$ In the German and Japanese systems, insufficient capital market liquidity-combined with the intense loyalty of the banks towards incumbent management-limits the ability of insurgent shareholders credibly to threaten a hostile takeover in the event that performance fails to improve.

This is not to suggest that the market for corporate control worked perfectly in the United States during the 1980s. Critics are correct to argue that share prices must decline too far before the market reacts. Rather, the point is that monitors in Germany and Japan also lack the incentive to intervene before firm values have declined significantly. Moreover, if the problem with the takeover market is that performance must decline too much before the market begins to operate, the solution is to design a regulatory system that decreases the costs of

155. See Macey, supra note 145 , at $472-73$. Naturally, some managers will divert their efforts to the legislative arena and work for legal protection, rather than aim for protection through robust performance in the market. Id.

156. Corporate Governance Survey, supra note 43 , at 16.

157. Id.

158. The paradigmatic American example of this threat is Warren Buffett of Berkshire Hathaway, Inc. Buffett does not threaten the continued existence of nonperforming companies, but rather the management of such companies, that is, he replaces the management of such companies with managers who are more likely to improve the company's performance. See id. 
intervention. This is not occurring in Germany, Japan, or the United States, largely because of the awesome power of incumbent management to resist change. ${ }^{159}$

\section{Rules Limiting Monitoring and Control by U.S. Intermediaries}

Perhaps the most effective criticism of the American system of corporate governance is that legal rules prevent American financial intermediaries from contractually protecting themselves against the moral hazard problem posed by shareholders. Although fixed claimants clearly have an incentive to monitor and control corporate borrowers, a variety of legal rules in the United States constrain fixed claimants' ability to control moral hazard. ${ }^{160}$ As Roe observes, "American legal restrictions have historically kept American banks small and weak, by banning them from operating nationally, entering commerce, affiliating with investment banks, equity mutual funds, or insurers, or from coordinating stockholdings with these other intermediaries."161 Our emphasis differs from Roe's. We are less interested in the ability of banks to dominate American corporate finance, and more concerned with legal restrictions that prevent American banks from even protecting their exposure as fixed claimants. These restrictions raise capital costs and reduce allocative efficiency by raising the costs of fixed claims in American firms.

In a nutshell, several American legal doctrines expose lenders to potential liability if they attempt to write contracts that protect themselves from borrowers' moral hazard. ${ }^{162}$ Many of these liability rules derive from the reasonable doctrine that banks have a general obligation of good faith toward borrowers, ${ }^{163}$ but courts often interpret them in a manner inconsistent with basic freedom of contract. As a result, expanded rules of lender liability have enabled

159. Japanese main bank intervention, for example, is consistently unlikely regardless of the firm's performance according to various indicia. See MORCK \& NAKAMURA, supra note 28, at 25-26, 55; see also Morck, Shleifer \& Vishny, supra note 31, at 850 (analyzing low turnover amongst Fortune 500 companies).

160. Mark Roe has chronicled a number of these rules. See Roe, supra note 115, at 16-31 (analyzing these rules in the context of financial institutions); Mark J. Roe, Political and Legal Restraints on Ownership and Control of Public Companies, 27 J. FIN. Econ. 7, 9-21 (1990) (describing how law constrains financial institutions' role in the corporate structure).

161. Roe, supra note 4 , at 1948.

162. See, e.g., United States v. Fleet Factors Corp., 901 F.2d 1550, 1557 (11th Cir. 1990) (holding that "a secured creditor may incur ... liability ... by participating the financial management of a facility to a degree indicating a capacity to influence the corporation's treatment of hazardous waste"), cert. denied, 498 U.S. 1046 (1991); K.M.C. Co. v. Irving Trust Co., 757 F.2d 752, 759-60 (6th Cir. 1985) (finding an implied good faith contractual obligation requiring a lender to give notice to a borrower before refusing to advance funds under their agreement); Brown v. Avemco Inv. Corp., 603 F.2d 1367, 1375-76 (9th Cir. 1979) (stating that a good faith belief of security impairment is needed to enforce an acceleration provision; technical breach is insufficient); Connor v. Great Western Sav. \& Loan Ass'n, 447 P.2d 609, 617-20 (Cal. 1968) (stating that a financier of home builders has a duty to exercise reasonable care in ascertaining that houses are not defective, and other parties' negligence does not insulate the financier from liability); State Nat'l Bank v. Farah Mfg. Co., 678 S.W.2d 661, 686 (Tex. Ct. App. 1984) (stating that a lender's attempts to enforce a management-change clause constituted duress).

163. MACEY \& MILLER, supra note 115, at 206. 
borrowers to transfer wealth to themselves by opportunistically suing banks when banks threaten to enforce their contracts with borrowers. ${ }^{164}$

When banks have threatened, for example, to enforce a management change clause (a contractual provision ostensibly allowing lenders to declare a default if top officers are appointed who are not approved by lenders), borrowers have been successful in suing banks for interfering with contractual relations between borrowers and their employees. ${ }^{165}$ Courts even have forced banks to loan more money or to give more advance notice of termination of a lending relationship than required by contract. ${ }^{166}$ Furthermore, banks which become actively involved in the affairs of borrowers in order to protect the value of their security interests may face massive liability for environmental harm the firm causes. ${ }^{167}$

Bankruptcy rules further chill American banks' incentive to take an active role in the affairs of borrowers, thereby discouraging intervention when it would be most helpful-when borrowers are in financial distress. Specifically, U.S. bankruptcy law strips senior lenders of their claims to collateral or subordinates their claims to those of junior lenders, or both, if the lender exercises some degree of control over the borrower. This principle, which is known as equitable subordination, provides a strong disincentive for banks to play an active role in corporate governance. In the classic American Lumber case, ${ }^{168}$ an American bank assisted in restructuring a troubled debtor after it had advanced the debtor extra funds. When the debtor began to fail despite these efforts, the bank tried to recover its funds. Other creditors complained of preferential treatment, and they persuaded the court to subordinate the bank's claims to theirs:

While [the bank] argues that subordination will cause members of the financial community to feel that they cannot give financial assistance to failing companies, but must instead foreclose on their security interests and collect debts swiftly, not leaving any chance for survival, the Court is singularly unimpressed. ${ }^{169}$

Thus, America's corporate governance problem may not stem from a lack of concentrated share blocks and powerful financial intermediaries as Roe suggests. ${ }^{170}$ Rather, the problem may arise from American courts' and legislatures' unwillingness to enforce the contractual provisions upon which financial intermediaries and borrowers agree. Enforcing such contractual provisions not

164. See Daniel R. Fischel, The Economics of Lender Liability, 99 Y ALE L.J. 131, 140-42 (I989) (discussing various interpretations of the duty of good faith and relevance of this duty in deterring opportunistic behavior by both lenders and borrowers).

165. See, e.g., Farah Mfg. Co., 678 S.W.2d at 690.

166. See, e.g., K.M.C. Co., 757 F.2d at 759-63.

167. See Fleet Factors Corp., 901 F.2d at 1557-68 (noting that a creditor may incur liability for a borrower's affairs if its participation in management indicates ability to intervene in the corporation's affairs). But see In re Bergsoe Metal Corp., 910 F.2d 668, 672 (9th Cir. 1990) (stating that "some actual management of the facility" is required to establish liability of secured creditor for a borrower's affairs).

168. In re American Lumber Co., 5 B.R. 470 (Bankr. D. Minn. 1980).

169. Id. at 478 .

170. See text accompanying note 161 supra. 
only would protect the banks from moral hazard but would also help borrowers avoid excessive borrowing costs.

\section{Convergence of the SyStems}

Some commentators have argued recently that American, German and Japanese systems of corporate governance are converging. ${ }^{171}$ For convergence to take place, however, three things would have to happen. First, German and Japanese banks would have to reduce their concentrated share ownership to promote more liquid capital markets and to develop a market for corporate control. Second, the German and Japanese systems would have to decrease bank control over corporate funding to facilitate the development of capital markets. And finally, of course, patterns of concentrated share ownership would have to emerge in the United States.

With regard to a decrease in concentrated levels of German and Japanese share ownership, no apparent convergence is taking place. In Germany, bank ownership of large blocks of stock is increasing, rather than decreasing, and in Japan bank ownership of stock has remained remarkably stable over time. ${ }^{172}$ It does appear, however, that German and Japanese banks are losing some of their ability to control corporate borrowers. ${ }^{173}$ Taken together, these two facts might suggest that corporate governance in Germany and Japan will improve as the banks' interests as shareholders begin to overwhelm their interests as fixed claimants. Although this is a distinct and promising possibility, it may not fully eliminate the conflicts that exist between banks and outside equity holders. These conflicts originate not only from the banks' status as fixed claimants, but also from the banks' capital structure, which is characterized by extremely highly leveraged portfolios and by substantial liability for demand deposits.

171. See, eg., Roe, supra note 4, at 1930.

172. Id. at 1959.

173. In $1991-1994$, for example, quoted Japanese nonfinancial firms sold $¥ 7.1$ trillion ( $\$ 60$ billion) in accumulated cross-shareholdings, reversing the post-war trend. Japan Inc Frays at the Edges, EcoNomist, June 3, 1995, at 67. In the first quarter of 1995, those firms sold another $¥ 340$ billion in cross-shareholdings. Id. Even if the first quarter trend continues through 1995, however, the resulting $¥ 1.36$ trillion reduction would represent only a tiny fraction of the $¥ 85$ trillion of accumulated Japanese cross-shareholdings. Id. Furthermore, while there is some increase in Japanese merger and acquisition activity, this increase is relatively insignificant. See Jathon Sapsford, Mergers' Growing Acceptance in Japan is Fortified by Fair Trade Panel's Move, Wall ST. J., Jan. 12, 1994, at A7 (discussing the Japanese Fair Trade Commission's reduction of regulatory burdens on mergers valued below $¥ 10$ billion (\$89 million). These nominal changes in favor of outside shareholders are unlikely to lead to a robust market for corporate control in the near future.

Nevertheless, the primacy of bank lending as a source Japanese and German corporate funding appears to be eroding. See RAMSEYER, supra note 55, at 12-14 (giving a historical summary of the entry of Japanese firms into the domestic bond market); Roe, supra note 4, at 1959-60 (stating that a worldwide trend toward debt-securitization is reducing the influence of commercial banks); Citibank Structuring German Deal to Add Investors, Asser SALES Rep., June 19, 1995, at 1, available in LEXIS, News Library, Curnws File (describing proposal to securitize German credit card receivables); Galleon Sets Sale for Germany, Asset SALES REP., Sep. 4, 1995, at 3, available in LEXIS, News Library, Curnws File (describing an agreement to securitize receivables from a mid-market German machine tool manufacturer); Lany Zoglin, Practice Serves Long Term Business Objectives: Stable Cross-Holding of Shares Likely to Withstand Pressures, JAPAN ECON. J., June 21, 1986, at 7, available in LEXIS, Asiapc Library, Allasi File (noting that corporate financing is trending away from bank loans toward the issuance of securities). 
Because this capital structure requires the banks to maintain stable cash fiows, German and Japanese banks have strong incentives to act like fixed claimants despite their substantial equity holdings in their clients.

Finally, commentators tentatively have hypothesized that American firms may be evolving "toward the German and Japanese style of ownership" because American financial intermediaries are taking a more active role in the management of the firms in which they invest. ${ }^{174}$ Commentators who analogize this emerging pattern of relational investing in the United States to the corporate governance structures of Germany and Japan fail to recognize the critical distinction between relational investors in the United States and banks in Germany and Japan. American financial intermediaries make equity investments, ${ }^{175}$ funding those investments with equity or long-term debt, ${ }^{176}$ whereas the German and Japanese banks make predominantly lending investments, funding them primarily with short-term debt. Thus, because American firms' power and authority to monitor is not compromised by the same conflicts of interest which characterize Japanese and German bank investments, the new American financial intermediaries probably will represent the interests of equity claimants more effectively than their Japanese and German counterparts.

Even if relational investing develops in the United States, the market for corporate control will remain critical to the success of America's corporate governance system. The effectiveness of large-block shareholders' efforts to influence and monitor American firms depends fundamentally on those relational investors' ability to threaten inefficient management with replacement. Unless incumbent management believes that large-block purchasers will take control or transfer their stakes to hostile bidders if performance falters, it has no reason to heed relational investors. In other words, the growth of relational investing complements, but does not replace, a robust market for corporate control. .

Responding to American banks' declining market share in the financial services sector of the world economy, legislators have recently offered several proposals to reduce the legal barriers that the Bank Holding Company Act of $1956^{177}$ and the Glass-Steagall Act ${ }^{178}$ pose to affiliations between banks and securities firms. As the banking industry's share of U.S. financial assets has

174. Roe, supra note 4, at 1965 . Warren Buffett's firm, Berkshire Hathaway, provides the model for America's new, relational form of investing. Similarly, Lazard Freres and Dillon Read, two American investment banks, now offer investment funds that specialize in identifying undervalued and poorly managed companies, and contributing managerial expertise to improving performance within these firms. Corporate Governance Survey, supra note 43, at 16.

175. See, e.g., Corporate Governance Survey, supra note 43, at 16 (reporting that the California Public Employees Retirement System (Calpers) "wants to enlarge its focus on underperformance by buying big stakes in troubled firms").

176. See, e.g., Briefly: Securities, L.A. TMes, Mar. 21, 1995, at D2 (reporting that Warren Buffet asked Berkshire Hathaway's shareholders to approve the issuance of up to one million new preferred shares because the firm "might need to issue such shares in future acquisitions").

177. 12 U.S.C. $\S \S 1841-1850$ (1994). The Bank Holding Company Act currently prohibits bank holding companies, which are firms that own or control banks, as well as the affiliates of bank holding companies, from holding the shares of any company that is not a bank, $\S 1843(\mathrm{a})(1)$, unless, among other things, the company's activities are "so closely related to banking or managing or controlling banks as to be a proper incident thereto," $\S 1843(c)(8)$. 
decreased from 66 percent to less than 30 percent over the last twenty years, ${ }^{179}$ and as American banks have disappeared from the ranks of the world's major financial institutions, policymakers have come to realize that allowing banks to affiliate with the providers of other financial services may enable the banking industry to compete in the global financial markets. ${ }^{180}$

These proposed reforms are important in the context of corporate governance because, in theory, they could support the argument that the financial industry in the United States is evolving in the direction of the German universal banks or the Japanese keiretsu. The proposed reforms to Glass-Steagall in the United States, however, are not likely to affect American corporate governance. In particular, they will not permit American banks to control the corporations with which they have lending relationships. The well developed capital markets for debt and equity in the United States provide outlets for American firms who need capital, thereby precluding dominance by commercial banks. In other words, even if American banks are allowed to make equity investments in firms to which they have loaned money, those banks will be unable to control the borrowers' corporate governance.

On February 2, 1995, Alfonse D'Amato, Chairman of the Senate Committee on Banking, Housing and Urban Affairs introduced the Depository Institution Affiliation Act (DIAA), ${ }^{181}$ and on February 27, 1995, Jim Leach, Chairman of the House Banking Committee, introduced the Financial Services Competitiveness Act of 1995. ${ }^{182}$ These proposals would transform bank holding companies into financial services holding companies, expanding the scope of permissible activities for the nonbank affiliates to include any activities deemed by the Board of Governors of the Federal Reserve System to be "financial in nature."183 Moreover, these proposals would expand the powers of holding companies' securities affiliates to permit them to underwrite corporate debt, equity and mutual fund shares. ${ }^{184}$ Finally, the legislation would modify the Glass-Steagall Act by allowing unlimited affiliation between commercial banks and investment banking organizations. ${ }^{185}$

178. The Banking Act of 1933 (Glass-Steagall), ch. 89, 48 Stat. 162 (1933) (codified as amended in scattered sections of 12 U.S.C.) generally requires the separation of commercial banking and merchant and investment banking activities. 12 U.S.C. $\$ \S 24,78,377,378$ (a) (1994).

179. Lise Simmons, Banking: D'Amato Introduces Sweeping Legislation Aimed at Financial Services Modernization, 1995 Daily Rep. for Execs. (BNA) No. 23, at A-23 (Feb. 3, 1995), available in LEXIS, News Library, Curnws File. A18.

180. Alfonse D'Amato, My Plan for a Stronger Financial Industry, WALr Sr. J., Feb. 2, 1995, at

181. S. 337, 104th Cong., 1st Sess. (1995). Representative Richard Baker offered a companion bill in the House on February 3, 1995. H.R. 814, 104th Cong., 1st Sess. (1995).

182. H.R. 1062, 104th Cong., 1st Sess. (1995).

183. H.R. 1062 § 150(1); S. $337 \S 101$ (a)(a); James Leach, 'A Two Way Street': Banking Panel's Bill Lets Securities Firms be Equal Partners, not Subsidiaries, of Banks, Roll Call, Mar. 27, 1995, available in LEXIS, News Library, Curnws File. Accordingly, the Bank Holding Company Act of 1956 would be renamed the "Financial Services Holding Company Act of 1995." Id.

184. H.R. 1062 § 103(a); S. 337 § 101(c)(10).

185. In particular, section 20 of the Glass-Steagall Act (codified as 12 U.S.C. $\S 377$ (1994)), which prohibits affiliations between banks and firms engaged principally in the securities business, would be repealed by the House bill, H.R. $1062 \S 101(a)$, and would be amended by the Senate bill to 
We strongly favor the liberalization of the Glass-Steagall Act to permit greater involvement by banks in the securities business. ${ }^{186}$ Greater commercial bank involvement in American corporate governance is not likely to give rise to the same problems engendered by German and Japanese bank activities because the structure of the American financial services sector will prevent bank domination present in the German, and to a lesser extent, the Japanese systems.

From the perspective of American banking organizations, greater involvement in the securities business will bring significant benefits in the form of lower risk through diversification, ${ }^{187}$ and lower operating costs through increased economies of scale and scope. In fact, studies have shown that far from increasing the riskiness of banking institutions, securities activities actually make banks safer. Eugene White, for example, found that the securities operations of commercial banks did not impair their stability prior to GlassSteagall - banks that engaged in securities activities did not have any higher earning variance or lower capital ratios than banks without such operations. ${ }^{188}$ Moreover, banks with securities operations were actually less likely to fail than banks without such operations. ${ }^{189}$ In the bank crisis at the height of the Great Depression, more than 25 percent of all U.S. national banks failed, but less than 10 percent of banks with securities affiliates failed. ${ }^{190}$

Banks and securities affiliates tend to share economies of scope because the information that banks gather in the course of making credit evaluations also can be used to make decisions regarding the underwriting and selling of the securities. Merging affiliates' data processing and other back-office operations will create economies of scale for the holding companies. Finally, the riskiness of bank lending activities can be reduced because, under the proposed legislation, banks may gain access to more extensive customer information through their affiliation with other enterprises, thereby enabling them to make more informed judgments regarding whether to extend credit to certain borrowers.

All these benefits can be realized without giving banks control over their corporate clients sufficient to harm the interests of nonbank shareholders. American banks will not have any expanded securities powers under the new legislative proposals; they will simply be allowed to form more extensive affiliations with securities firms. And American securities firms, unlike European

permit unlimited affiliations between securities affiliates and other affiliates of the financial services holding company. S. $337 \S 104$ (a).

186. One of us has argued that there are no plausible public interest justifications for the GlassSteagall restrictions on banks' securities activities, and that the most convincing explanation for the statute's enactment is that special interest groups within the banking industry succeeded in persuading Congress to cartelize the economy's banking sector. Jonathan R. Macey, Special Interest Groups Legislation and the Judicial Function: The Dilemma of Glass-Steagall, 33 EMORY L.J. 1, 1-2 (1984).

187. See Jonathan R. Macey, M. Wayne Marr \& S. David Young, The Glass-Steagall Act and the Riskiness of Financial Intermediaries, 14 RES. L. \& EcoN. 19, 25-27 (1991) (explaining that firms engaged in both commercial and investment banking may not be riskier than firms engaged only in commercial banking).

188. Eugene White, Before the Glass-Steagall Act: An Analysis of the Investment Banking Activities of National Banks, 23 ExploRATIONS ECON. Hist. 33 (1986).

189. Randall S. Kroszner \& Raghuram G. Rajam, Is the Glass-Steagall Act Justified? A Study of the U.S. Experience with Universal Banking Before 1933, 84 AM. Econ. Rev. 810, 811 n.3 (1994).

190. White supra note 188 , at 40. 
banks, make a point of refraining from intrusion into the corporate governance of their clients. Rather, American investment banks limit their activities to underwriting, trading, and providing general investment banking advice about mergers and acquisitions and corporate finance.

American investment banks are further unlikely to disrupt internal corporate affairs because the U.S. financial services sector is uniquely characterized both by intense competition and by heterogeneity. Investment banking firms which attempted to make unwelcome intrusions into the corporate governance of their clients would quickly find themselves without clients because, unlike Japanese and German corporations, American firms can switch investment banking relationships with impunity. Moreover, in the United States, powerful, independent, nonbank institutional investors such as insurance companies, pension funds, and mutual funds, would strongly object to efforts by financial services holding companies to assert themselves in the corporate governance of publicly traded companies.

Path dependence provides a final reason why the current proposals to liberalize the scope of permissible bank affiliations does not pose any cognizable danger to the corporate governance of American firms. Simply put, for the reasons we have advanced in this article, American capital markets have replaced the languishing domestic banking industry as the principal supplier of capital to American industry. Consequently, it is too late for American banking organizations to use their influence over corporate governance to retard the growth of American capital markets.

Thus, by permitting the new affiliations, the proposed reforms could strengthen the American banking industry, but the proposals do not, in and of themselves, pose the danger that banking institutions will use their influence over corporate clients to advance their interests as lenders at the expense of other shareholders.

\section{CONCLUSION}

Vigorous competition in the product and labor markets is most powerful corporate governance device of all. Competition in the marketplace forces firms to compete fervently for capital. For this reason, the rapid globalization of trade and investment should lead to improved corporate governance throughout the world. Naturally, those economies with the best corporate governance structures will outperform rival economies at the margin.

The purpose of this Article has been to show that the "continuous and textured" monitoring that characterizes relational investing in Japan and Germany is not a panacea. The problems posed by these systems result from straightforward conflicts of interest between risk-averse fixed claimants, who control investments, and residual claimants, who have the greatest stake in the firm's financial success. The highly leveraged capital structure of banks and their large exposure to demand deposits further enhance the banks' conservative tendencies. Because banks' risk preferences are more closely aligned with man- 
agement's than with those of equity investors-or society-banks make poor monitors and cannot be expected to maximize the value of the firm.

The failure of existing theories of relational investing to recognize the conflict of interest between equity markets and fixed claimants exemplifies an unfortunate tendency to treat all financial intermediaries alike. ${ }^{191}$ Moreover, commentators who extol the virtues of bank dominated corporate governance systems fail to consider adequately the adverse effects such systems have had on the development of capital markets in the countries that have employed them. Put differently, the strong role played by financial intermediaries has retarded the growth of primary and secondary markets for equity, and has thereby stifled an important source of risk capital for firms.

The American corporate governance system is by no means perfect. In the United States, shareholders must rely on the threat of a takeover to discipline managers. Outside bidders protect shareholder interests by monitoring management in publicly traded firms and by launching hostile bids when firms underperform. But in recent years, politics has interfered with the efficacy of the market for corporate control: State antitakeover statutes have dramatically reduced the number of hostile takeovers in the United States, diverting wealth from shareholders, who must endure firms' suboptimal performance, to managers, who no longer face the threat of displacement. In the absence of a healthy takeover market, the weakness of American financial intermediaries is disturbing. Unfortunately, several American legal doctrines have artificially limited the ability of banks to monitor corporate borrowers. As a result, while the degree of banks' influence in Germany and Japan is probably excessive, the level of banks' influence in the United States is likely too low.

The problem in Germany and Japan is that the interests of equity investors are insufficiently represented in corporate governance. The problem in the United States is that fixed claimants are unable to protect themselves contractually from the moral hazard posed by the equity-dominated corporate borrowers. Both of these deficiencies in corporate governance structures raise the cost of capital and reduce allocational efficiency. Rather than investing resources in copying each others' systems, each system would profit by focusing on, and repairing, its own problems.

191. See, e.g., Helen Garten, Institutional Investors and the New Financial Order, 44 Rurgers L. REv. 585, 590-91 (1992) (describing two models of institutional influence-the "stability" model and the "profitability" model). Challenges to this trend are increasing. See Richard M. Buxbaum, Comparative Aspects of Institutional Investment and Corporate Governance, in INSTITUTIONAL INVESTORS AND CORPORATE GOVERNANCE, supra note 34, at 3, 13 (challenging the common wisdom that pension-fund backed investors necessarily behave as typical equitable shareowners, and suggesting that they have more in common with fixed claimants). 